
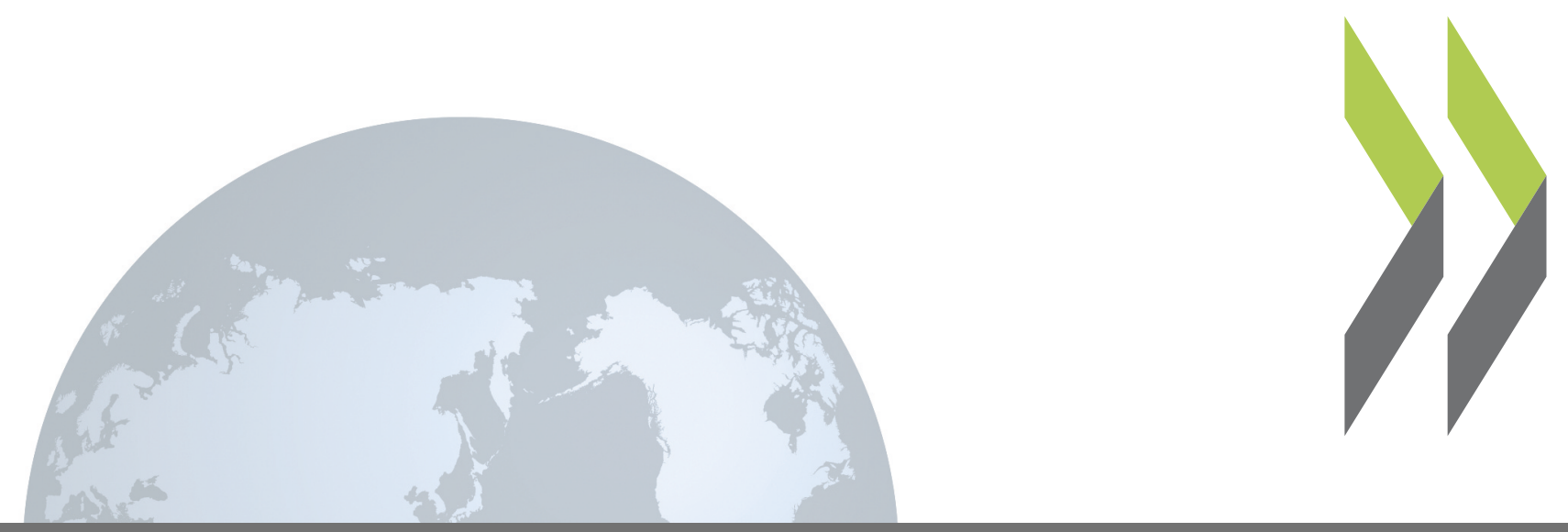

OECD Economics Department Working Papers No. 1595

Firming up the capital base of the Austrian business sector - Consolidating Austria's business sector strengths and its social role in the face of new
challenges
Dennis Dlugosch, Rauf Gönenç, Eun Jung Kim,

\section{Aleksandra Paciorek}


ECONOMICS DEPARTMENT

FIRMING UP THE CAPITAL BASE OF THE AUSTRIAN BUSINESS SECTOR

- CONSOLIDATING AUSTRIA'S BUSINESS SECTOR STRENGTHS AND ITS SOCIAL ROLE IN THE FACE OF NEW CHALLENGES

\section{ECONOMICS DEPARTMENT WORKING PAPERS No. 1595}

By Dennis Dlugosch, Rauf Gönenç, Eun-Jung Kim and Aleksandra Paciorek

OECD Working Papers should not be reported as representing the official views of the OECD or of its member countries. The opinions expressed and arguments employed are those of the author(s).

Authorised for publication by Isabell Koske, Deputy Director, Country Studies Branch, Economics Department.

All Economics Department Working Papers are available at www.oecd.org/eco/workingpapers.

JT03457185 
OECD Working Papers should not be reported as representing the official views of the OECD or of its member countries. The opinions expressed and arguments employed are those of the author(s).

Working Papers describe preliminary results or research in progress by the author(s) and are published to stimulate discussion on a broad range of issues on which the OECD works.

Comments on Working Papers are welcomed, and may be sent to OECD Economics Department, 2 rue André Pascal, 75775 Paris Cedex 16, France, or by e-mail to eco.contact@oecd.org.

All Economics Department Working Papers are available at www.oecd.org/eco/workingpapers.

On 25 May 2018, the OECD Council invited Colombia to become a Member. At the time of preparation the deposit of Colombia's instrument of accession to the OECD Convention was pending and therefore Colombia does not appear in the list of OECD Members and is not included in the OECD zone aggregates.

The statistical data for Israel are supplied by and under the responsibility of the relevant Israeli authorities. The use of such data by the OECD is without prejudice to the status of the Golan Heights, East Jerusalem and Israeli settlements in the West Bank under the terms of international law.

This document and any map included herein are without prejudice to the status of or sovereignty over any territory, to the delimitation of international frontiers and boundaries and to the name of any territory, city or area.

\section{(C) OECD (2020)}

You can copy, download or print OECD content for your own use, and you can include excerpts from OECD publications, databases and multimedia products in your own documents, presentations, blogs, websites and teaching materials, provided that suitable acknowledgment of OECD as source and copyright owner is given. All requests for commercial use and translation rights should be submitted to rights@oecd.org. 


\section{ABSTRACT/RESUMÉ}

Firming up the capital base of the Austrian business sector - Consolidating Austria's business sector strengths and its social role in the face of new challenges

While small- and medium sized firms in Austria are generally more productive, export more, and engage more in higher technology activities than in comparable countries, they need to adapt better to the knowledge economy to maintain their relative performance levels. The capital structure of Austrian SMEs are biased towards debt-financing and stronger equity, growth and venture capital markets would provide them with further resources for their long-term knowledge based investments. Skills shortages, in particular in advanced digital technologies, should be overcome. As around one third of all SMEs are up for ownership transmissions, ensuring successful business transfers will be crucial for maintaining the broad-based entrepreneurial dynamism. Meeting these challenges would also help to lift constraints on upscaling that many SMEs face and would provide the fruitful soil for future innovative activities.

This Working Paper relates to the 2019 OECD Economic Survey of Austria (http://www.oecd.org/economy/austria-economic-snapshot/)

JEL codes: E22, G30, G32, G38, G21, J11, J21

Keywords: capital structure of SMEs, debt-financing, allowance for corporate equity, skill shortages, ownership transmissions

Renforcer la structure de capital du secteur des entreprises en Autriche - consolider les atouts et le rôle social du secteur des entreprises face aux nouveaux défis

Alors que les petites et moyennes entreprises autrichiennes sont généralement plus productives, exportent davantage et s'engagent davantage dans des activités de haute technologie que dans des pays comparables, elles doivent mieux s'adapter à l'économie du savoir pour maintenir leurs niveaux de performance relatifs. La structure du capital des PME autrichiennes est orientée vers le financement par emprunt. Des marchés d'actions, de croissance et de capital-risque plus solides leur fourniraient des ressources supplémentaires pour leurs investissements à long terme fondés sur la connaissance. Les pénuries de compétences, en particulier dans les technologies numériques avancées, devraient aussi être surmontées. Étant donné qu'environ un tiers de toutes les PME sont destinées à des transmissions de propriété, il sera essentiel de garantir la réussite ces transferts pour maintenir le dynamisme entrepreneurial de l'économie. Relever ces défis contribuerait également à lever les contraintes de croissance de taille auxquelles de nombreuses PME sont confrontées et fournirait un terrain fertile pour de futures activités innovantes.

Ce Document de travail se rapporte à l'Étude économique de l'OCDE de l'Israël 2019 http://www.oecd.org/fr/economie/autriche-en-un-coup-d-oeil/

JEL classification : E22, G30, G32, G38, G21, J11, J21

Mots de Clé s: structure du capital des PME, financement par emprunt, déduction pour fonds propres pénuries de compétences, transmissions de propriété 


\section{Table of contents}

\section{Firming up the capital base of the Austrian business sector - Consolidating Austria's business sector strengths and its social role in the face of new challenges}

\section{Tables}

Table 1. Firm-level regression results

Table 2. Institutions, economic development, and listings per capital

Table 3. Employment and turnover affected through potential business transfers in SMEs

Annex Table 1.A.1. Institutions, economic development, and listings per capita

\section{Figures}

Figure 1. Medium-sized manufacturing firms play an important role in Austria

Figure 2. Lower contribution to value added but similar share of exports confirm high export orientation of Austrian SMEs

Figure 3. Austrian SMEs are more likely to engage in exporting

Figure 4. Austrian SMEs contribute more to medium-high to high-tech sectors and knowledge-intensive market services

Figure 5. Austrian SMEs in manufacturing sectors close to productivity of top performers but lag behind in service sectors

Figure 6. Weak productivity growth in service sectors drags on aggregate productivity growth

Figure 7. Overall productivity performance masks differences between sectors

Figure 8. SMEs perform comparatively well on productivity, but larger firms lag further behind the global frontier

Figure 9. Demographic change reduces the size of Austria's talent pool

Figure 10. Business investment is above pre-crisis levels with shift towards intangibles

Figure 11. High debt-to-equity ratios but moderate total leverage point to lack of equity capital

Figure 12. High capital intensity and prevalence of family-owned enterprises lead to high debt-to-equity ratios in tourism industries

Figure 13. Debt-to-equity ratios of Austrian SMEs are higher than in peer countries

Figure 14. Bank loans are the most important form of external credit for small- and medium-sized firms

Figure 15. Austria has the lowest stock market capitalisation in the OECD and the market lacks liquidity

Figure 16. Number of listings per GDP (1 million USD)

Figure 17. Protection of minority shareholder interests across countries

Figure 18. Estimates of Austria's listing gap

Figure 19. Young firms are successful in surviving the first years but do not grow large

Figure 20. Venture capital markets lag behind

Figure 21. Growth capital markets are not well developed

Figure 22. Revenue and rates for corporate income tax

Figure 23. Effective marginal corporate income tax rates are high particularly for intangible investment

Figure 24. Employment in Austria lost middle-skilled jobs but gained high-skilled jobs

Figure 25. Austria attracts many international students but few stay after graduation

Figure 26. Austrians perceive themselves as capable for entrepreneurial activity...

Figure 27. ... and have less fear of failing than elsewhere

\section{Boxes}

Box 1. Key characteristics of the Austrian business landscape 


\title{
Firming up the capital base of the Austrian business sector - Consolidating Austria's business sector strengths and its social role in the face of new challenges
}

\author{
By Dennis Dlugosch, Rauf Gönenç, Eun-Jung Kim and Aleksandra Paciorek ${ }^{1}$
}

\section{Challenges and opportunities for Austria's business sector in a changing world}

Austrian small- and medium-sized enterprises in manufacturing sectors tend to be more productive, engage more in exporting and contribute more to medium-high- and high-tech manufacturing activities and knowledge-intensive market service sectors than in comparable economies (Box 1). Through entrepreneurship, SMEs can foster social inclusion of otherwise disadvantaged groups, like migrants, women, young but also the elderly.

However, the performance of these sectors in Austria has been less impressive over the last decade and it faces significant challenges from global trends, including demographic change, digitalisation, global value chain integration and adaption to new environmental regulations and prices. This chapter focusses on key factors, which limit the potential of Austrian SMEs to adapt and upscale, while taking into account the defining features of the Austrian economy. It identifies the following three key challenges:

- The capital structure of SMEs is biased towards debt-financing: Austrian small- and medium-sized enterprises have one of the highest debt-to-equity ratios across OECD countries and are strongly reliant on bank debt and internal sources to finance increases in capacity. While the relationshipbanking model is a strength of the Austrian economy, a general lack of risk capital tends to hinder investment in new and experimental technologies and business applications, including specific ICT applications, knowledge-based capital. Austria has abnormally few stock market listings even after taking the size of the economy and the legal framework into account. This reflects the general lack of demand for equity investments of Austrians but also structural impediments. Further, venture and growth capital markets are less developed than elsewhere.

- Skill shortages: The vast majority of Austrian SMEs report skills shortage as a major obstacle to growth. The skills shortage is particularly pronounced for ICT specialist skills, thus constraining the adoption of ICT applications and higher productivity.

- Business transfers: Around 30\% of Austrian SMEs are up for ownership transmission in the 20142023 period, a critical stage in the lifecycle of a company. Ensuring successful business transfers of economically vibrant enterprises is vital for employment and productivity growth.

Addressing these challenges can lift the constraints on upscaling many Austrian SMEs are facing while providing fruitful soil for innovative activity. Ageing of the Austrian society and the digital transformation may result in significant changes to traditional ways of doing business. Framework conditions conducive to competition, innovation and business growth can deliver synergies by diminishing current constraints and preparing for these substantial changes. Policies need to be innovative too in order to deal with challenges and should be open to new avenues without jeopardizing the defining features of the Austrian economy.

The first section of this chapter discusses these trends, how the Austrian SMEs might be affected and concludes with an analysis of recent trends in productivity performance of the Austrian business sector. The second section takes an in-depth look at capital structures of Austrian businesses and analyses the provision of debt but also risk capital. The third section discuss how policymakers can address skills shortages and the fourth section how to provide the right ground for successful business transfers.

\footnotetext{
${ }^{1}$ An earlier version of this paper benefited from the comments of Sebastian Barnes, Patrick Lenain and Isabell Koske. Heloise Wickramanayake provided editorial support. The corresponding author is Dennis Dlugosch, email: dennis.dlugosch@oecd.org.
} 


\section{Box 1. Key characteristics of the Austrian business landscape}

- The definition of SMEs used in this chapter rests on employment numbers. It defines a SME enterprise as having between 0 and 249 employees, in line with the definition of Eurostat. As incentives to self-employment and entrepreneurship vary across countries, it is sometimes helpful to disentangle micro- and small companies (0-49 employees) from medium-sized enterprises (50-249 employees).

- Austria has a similar share of SMEs in the total business population as elsewhere. The Austrian business economy consists of over 300000 firms, of which $99.7 \%$ were SMEs, nearly identical to the OECD average (Figure 1 Panel A). SMEs provided around $69 \%$ of total employment in business sectors, slightly above the OECD average. The share of medium-sized companies is also broadly in line with the OECD average. Similarly for total employment in business sectors, where Austrian medium-sized companies provide around $19 \%$ of all jobs, compared to the OECD average of $18.6 \%$.

- In manufacturing sectors, significantly more firms are medium-sized than in the OECD average. This coincides with lower shares of SME firms (Figure 2.1 Panel B), which suggests that medium- and large-sized firms play a larger role than in the typical OECD country, though lower as compared to neighbouring and peer countries.

- Austrian SMEs have a higher export orientation (Figure 2). The share of SMEs exporting in Austria is one of the highest across OECD countries (Figure 3). This implies that Austrian SMEs are more exposed to the benefits but also the challenges from increased globalisation, even taking into account that statistics on direct exports and imports may understate the role of SMEs in international global value chains. After accounting for the inputs of SMEs to large exporters, the share of Austrian SMEs in value added exports jumps to over 50\% (OECD, 2018).

- SMEs account for higher shares of value added in medium-high- and high-technology sectors than in peer countries (Figure 4, Panel A). Their contribution to value added in these sectors is around $30 \%$ against $25 \%$ in the OECD average and $22 \%$ in peer countries. This goes hand in hand with slightly smaller shares in medium-low- and low-technology sectors than in peer countries or the OECD average.

- Austrian SMEs contribute more to value added in business service sectors, in particular in knowledge-intensive business services (Figure 4, Panel B). Around $82 \%$ of value added in knowledge-intensive business market services is produced by SMEs compared to roughly $60 \%$ in peer countries of the OECD average. With $72 \%$ of total value added in business service sectors, Austrian SMEs are responsible for significantly more output than in the OECD average or peer countries where around $60 \%$ of value added comes from SMEs.

- Austrian SMEs are close to the top performing SMEs across OECD countries for productivity in manufacturing (Figure 5). Further, Austrian SMEs have the smallest gap as compared with peer countries and the OECD average in medium-high to high-tech sectors. 


\section{Figure 1. Medium-sized manufacturing firms play an important role in Austria}

Share of SMEs and medium-sized enterprises in the total firms, 2016 or latest year

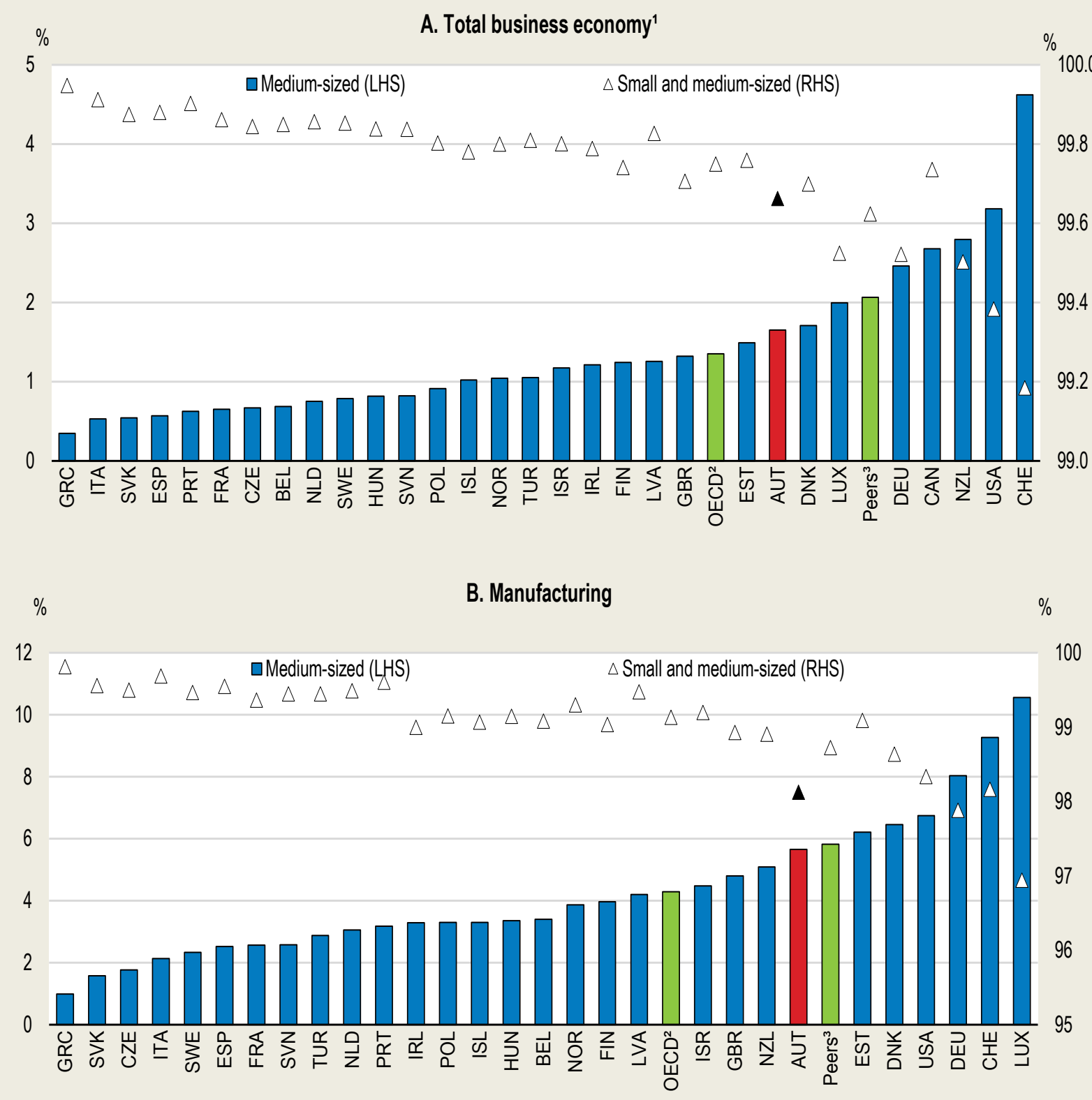

1. It covers non-agriculture business sectors excluding real estate.

2. Unweighted average of the data shown.

3. Unweighted average of Denmark, Sweden, Germany, Switzerland and the Netherlands.

Source: OECD (2018), Structural and Demographic Business Statistics (database). 
Figure 2. Lower contribution to value added but similar share of exports confirm high export orientation of Austrian SMEs

Share of SMEs in the total firms, manufacturing, 2016 or latest year

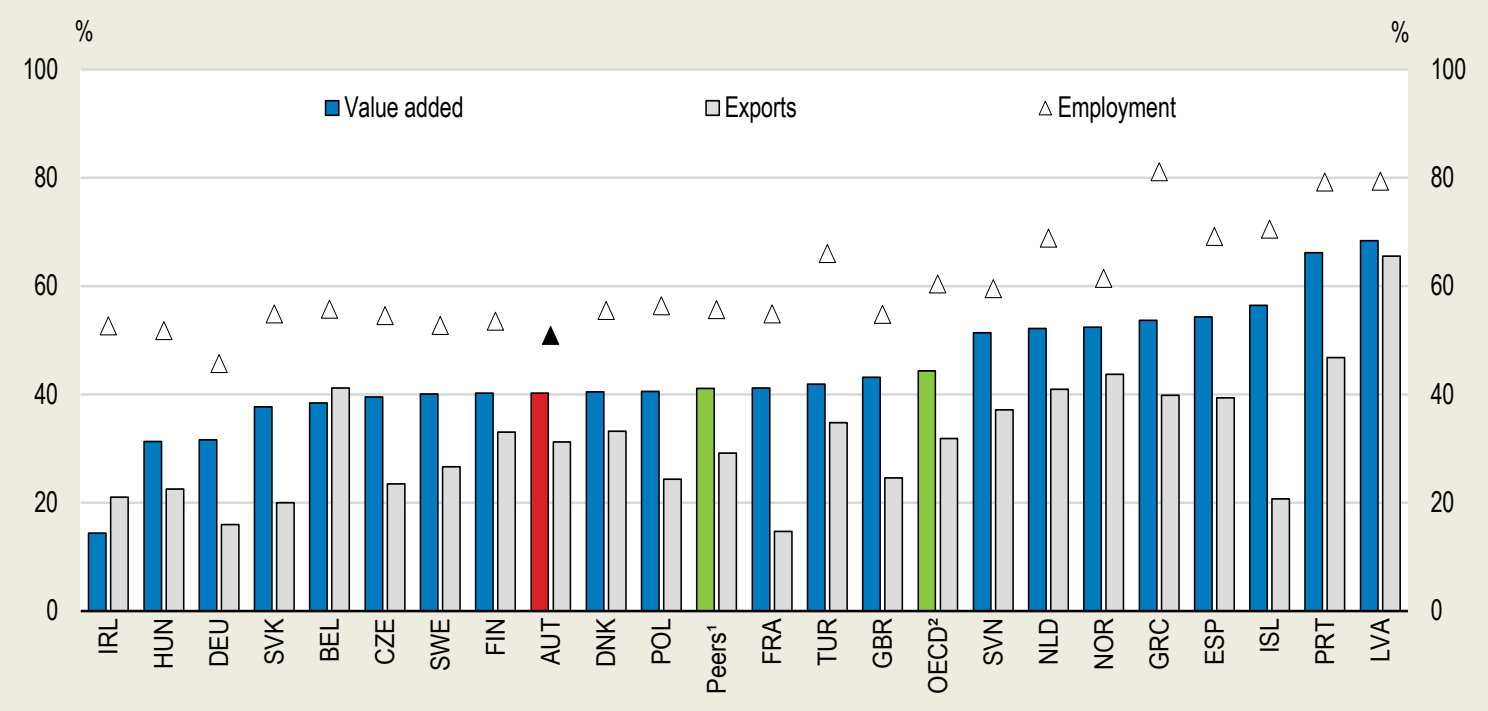

1. Unweighted average of Denmark, Sweden, Germany, Switzerland and the Netherlands.

2. Unweighted average of the data shown.

Source: OECD (2018), Structural and Demographic Business Statistics (database) and OECD (2019), "Trade by enterprise characteristics: Trade by activity sectors (Edition 2018)", OECD Statistics on Measuring Globalisation (database).

\section{Figure 3. Austrian SMEs are more likely to engage in exporting}

Share of SMEs exporting, 2016 or latest year

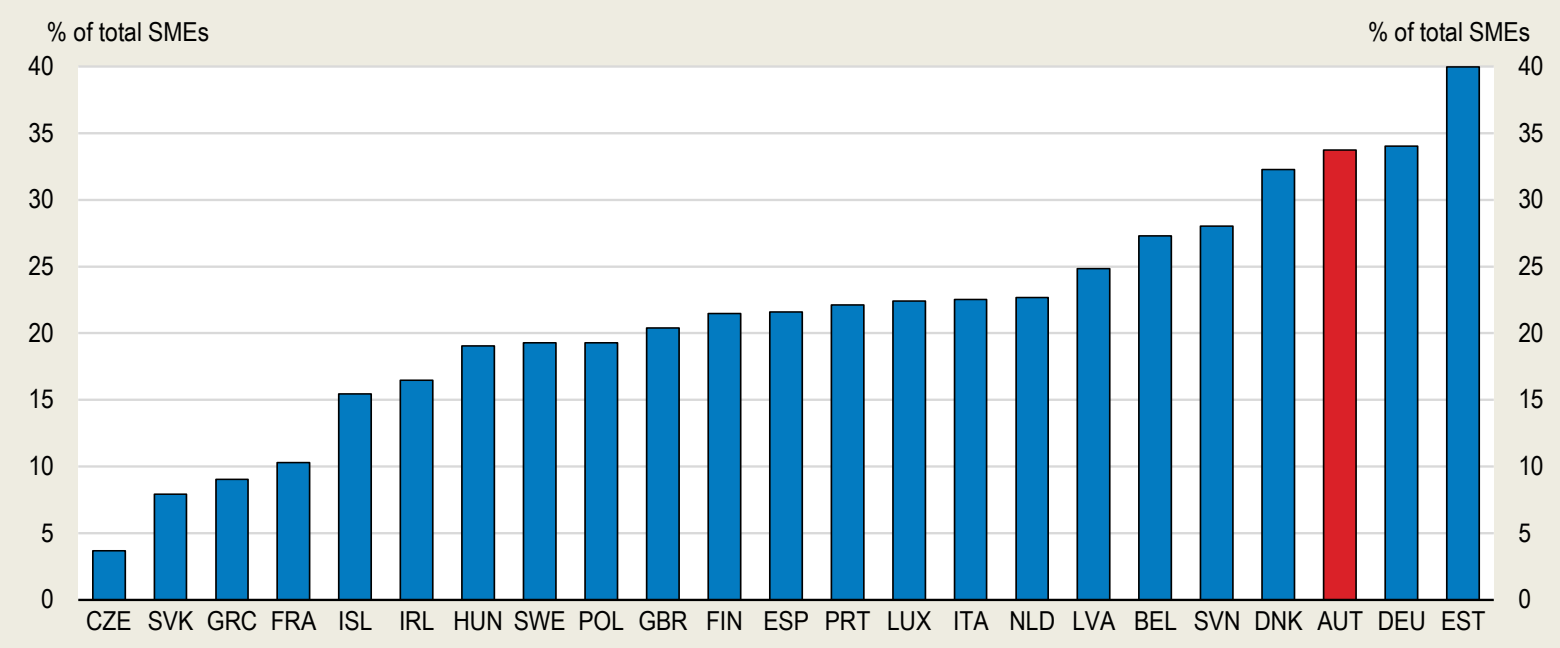

Note: Exporting SMEs include all SMEs which export to any country worldwide.

Source: OECD (2018), Structural and Demographic Business Statistics (database) and OECD (2019), "Trade by enterprise characteristics: Trade by activity sectors (Edition 2018)", OECD Statistics on Measuring Globalisation (database). 
Figure 4. Austrian SMEs contribute more to medium-high to high-tech sectors and knowledgeintensive market services

Share of total value added per sector, SMEs, 2015
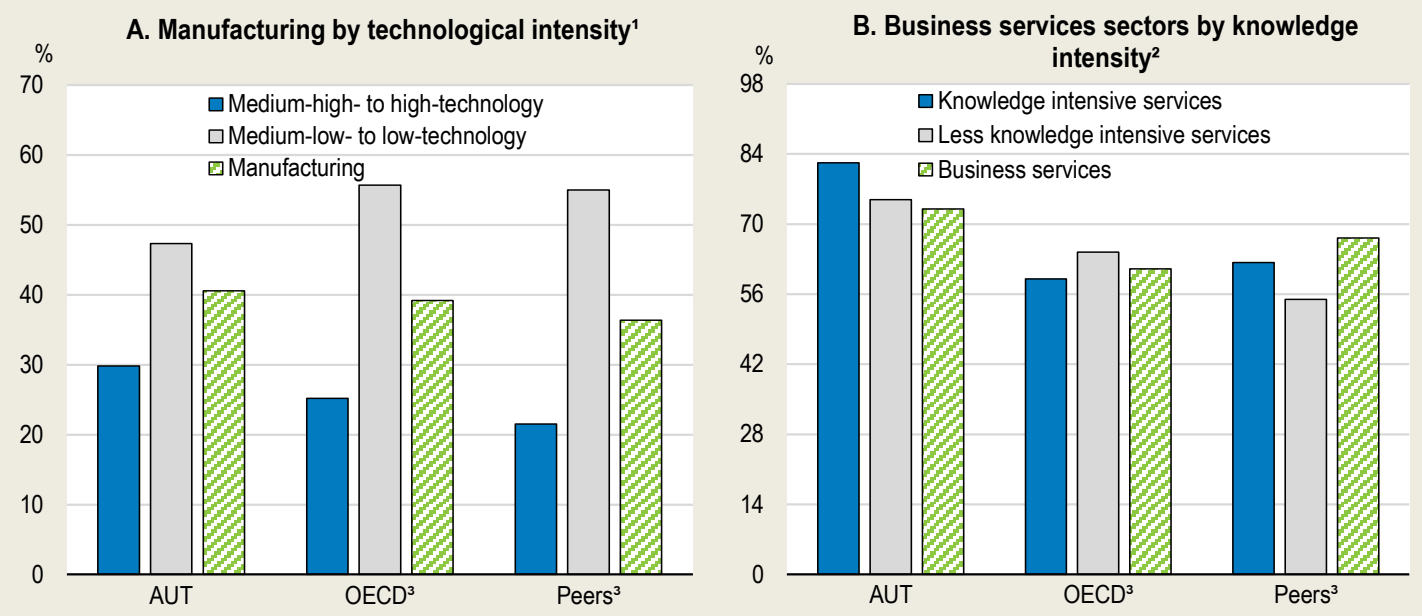

1. It consists of the following NACE Rev.2. sections: (1) medium-high- to high-technology manufacturing sectors refer to the sections 20,21 , 26 and 27 to 30, (2) medium-low- to low-technology sectors refer to other manufacturing sections.

2. It consists of the following NACE Rev.2. sections: (1) knowledge-intensive services refer to the sectors 50 to 51,69 to 71,73 to 74,78 and 80. (2) less knowledge-intensive services refer to the sectors 45 to $47,49,52,55$ to $56,68,77,79,81,82$ and 95 . Business services exclude both real estate and financial services.

3. Peer countries is the unweighted average of Germany, Switzerland, Denmark, Sweden and the Netherlands. OECD is the unweighted average of $32 \mathrm{OECD}$ countries.

Source: OECD (2018), Structural and Demographic Business Statistics (database).

Figure 5. Austrian SMEs in manufacturing sectors close to productivity of top performers but lag behind in service sectors

Productivity' of SMEs in per cent of top performer, 2016

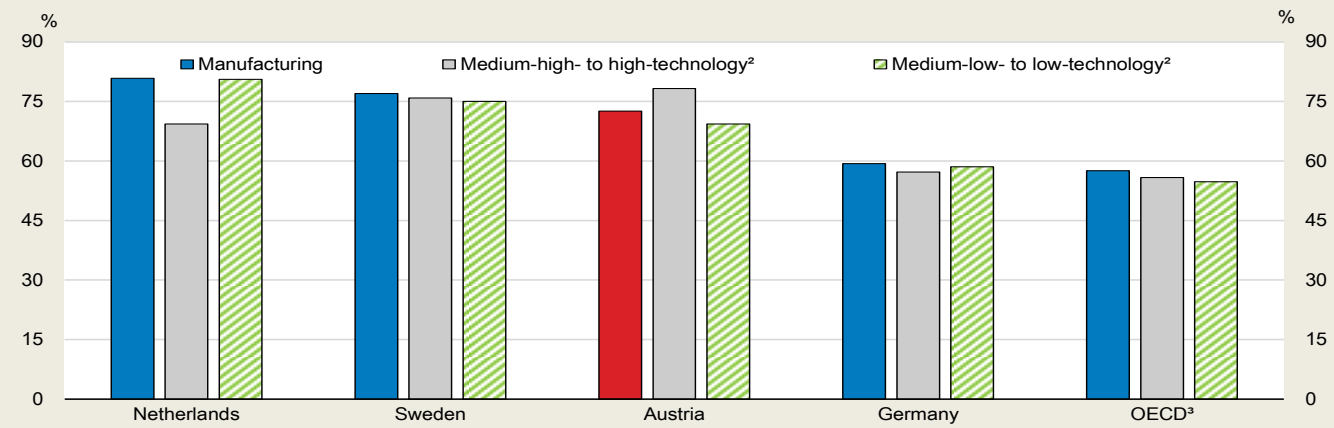

1. Productivity is measured as real value added (converted into euros using 2016 exchange rates) per hour worked.

2. It consists of the following NACE Rev.2. sections: (1) medium-high- to high-technology manufacturing sectors refer to the sections 20, 21, 26 and 27 to 30, (2) medium-low- to low-technology sectors refer to other manufacturing sections.

3. OECD is the unweighted average of 29 OECD countries.

Source: OECD (2018), Structural and Demographic Business Statistics (database). 


\section{Productivity growth of Austrian businesses has declined}

Productivity growth in the Austrian business economy has declined. Whereas annual average productivity growth was around $2 \%$ in the period from $1995-2003$, it diminished to $0.6 \%$ in the post-crisis period (Figure 6, Panel A). This may reflect structural impediments to innovative activity and productivity but also illustrates, that at high levels, margins for further improvement are more difficult to exploit (Gordon, 2012). Peer countries and countries from the European Union, experienced a similar slowdown, so Austria is far from alone to experience this slowdown (Figure 6, Panel B).

\section{Figure 6. Weak productivity growth in service sectors drags on aggregate productivity growth}

Compounded average annual growth, labour productivity by sector

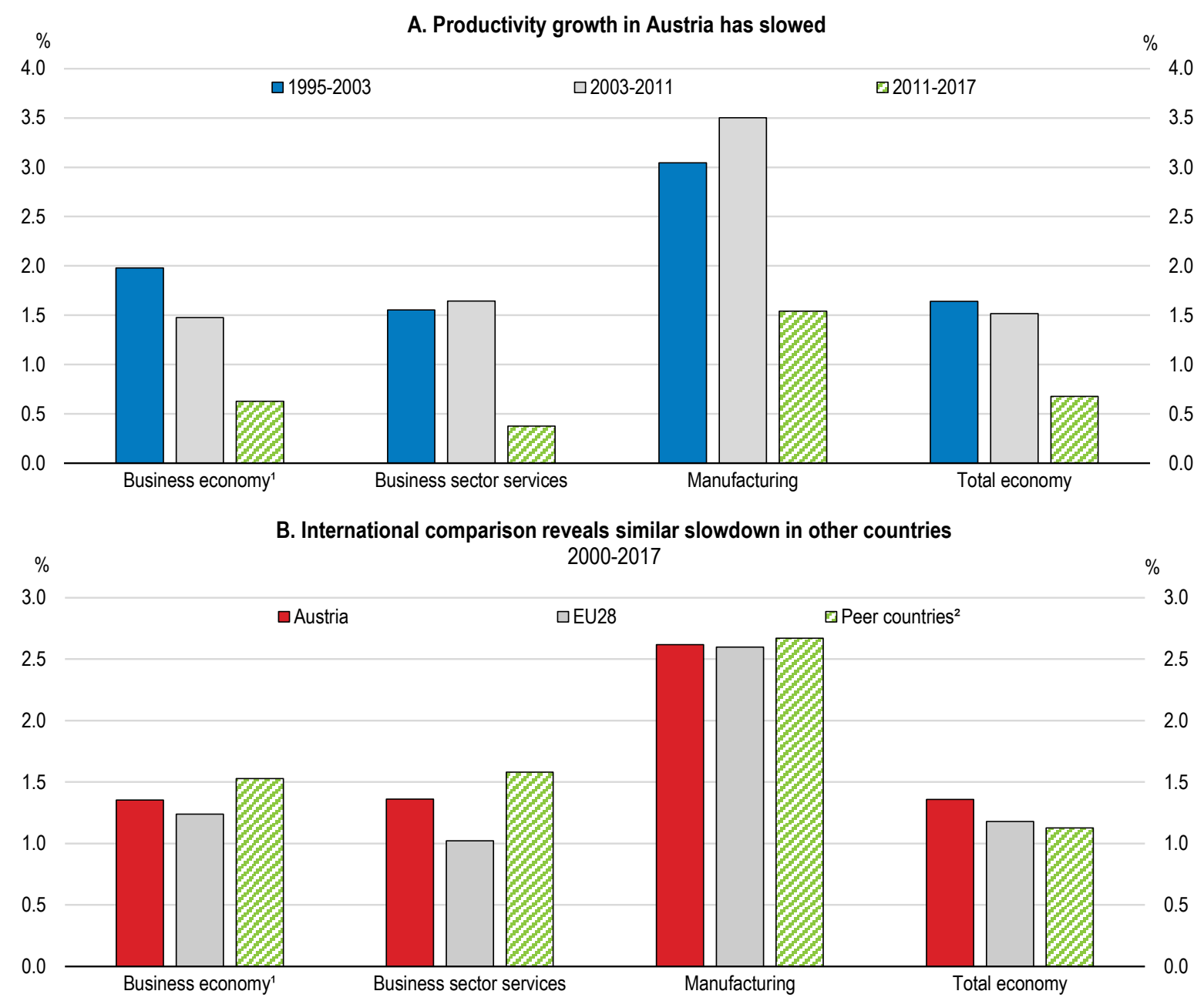

1. It covers non-agriculture business sector excluding real estate.

2. Unweighted average of Denmark, Sweden, Germany, Switzerland and the Netherlands.

Source: OECD (2018), OECD Structural Analysis Statistics (database).

Overall business sector productivity growth masks large differences in the performance of specific sectors. Besides business services, Austria falls behind in sectors with high R\&D activity and in ICT manufacturing and services (Figure 7, Panel A). The annual difference in productivity growth in ICT manufacturing and service sectors and high R\&D activities compared to peer countries is large. Productivity growth in 
manufacturing sectors was above peer countries but below the US (Figure 7, Panel B). The productivity performance was driven by strong growth in medium-high to high-tech sectors, where growth rates were on average 1 percentage points higher than in peer countries.

\section{Figure 7. Overall productivity performance masks differences between sectors}

Compounded average annual productivity growth, business economy ${ }^{1}, 2000-2015$

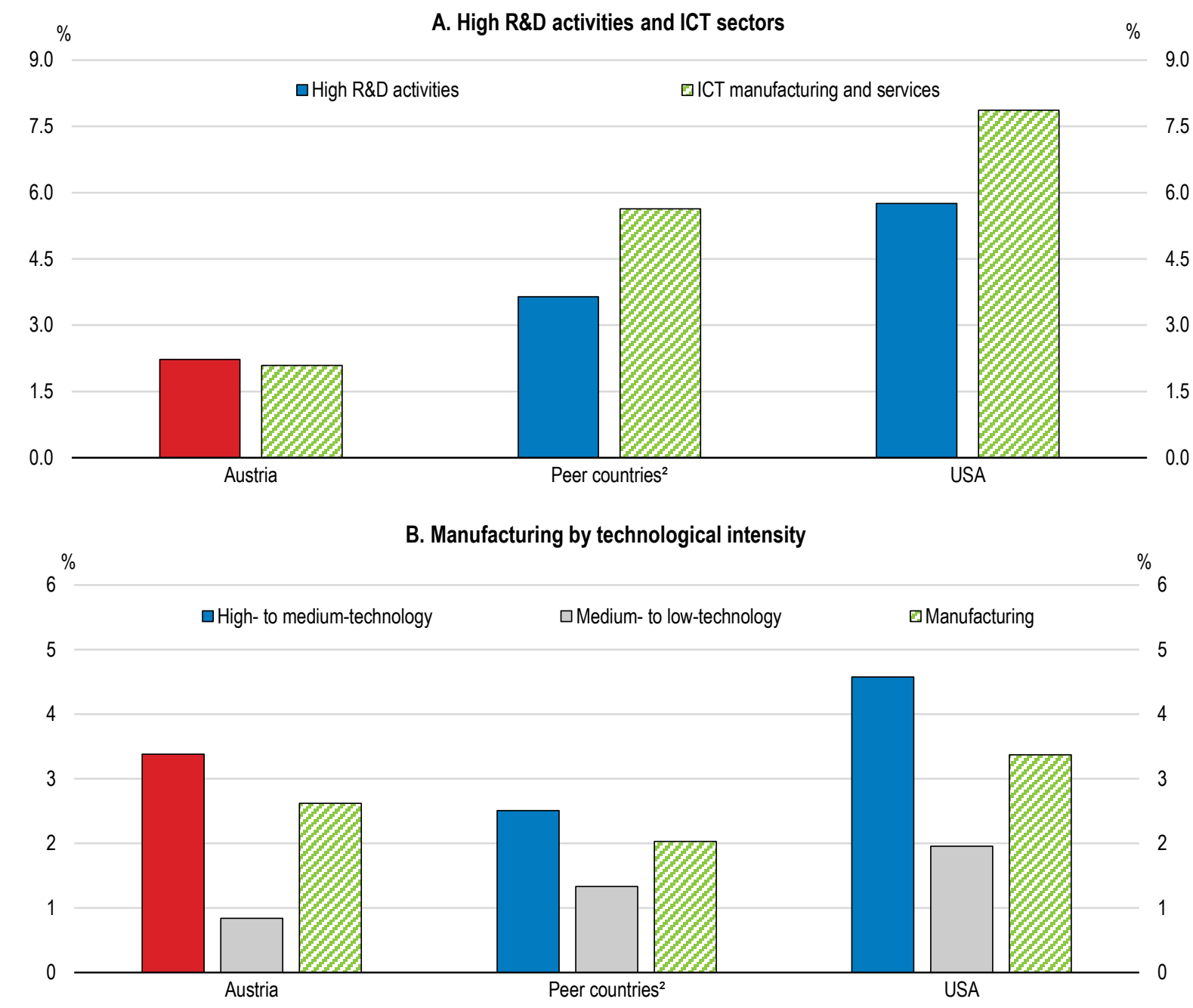

1. It covers non-agriculture business sector excluding real estate.

2. Unweighted average of Denmark, Sweden, Germany, Switzerland and the Netherlands.

Source: OECD (2018), OECD Structural Analysis Statistics (database).

The productivity gap between SMEs and large enterprises in manufacturing sectors is much smaller in Austria than in peer countries or the OECD average. This small gap is driven by the productivity performance of medium-sized firms, which attain $90 \%$ of the productivity level of large firms (Figure 8 , Panel A). In medium-high to high-tech manufacturing sectors, the gap is even narrower and SMEs have nearly the same productivity as large companies. This is surprising, as high shares of fixed assets in most manufacturing sectors typically allow larger firms to exploit returns to scale and subsequently materialise in higher productivity performance. However, the small gap can be partly explained by the weaker productivity performance of larger firms in Austria than elsewhere (Figure 8, Panel B). Austrian large firms 
achieve only around $60 \%$ of the productivity level of the top-performing large companies across the OECD, which is above the OECD average but below peer countries. The gap to the top-performing large firms is even more pronounced in medium-high to high-tech manufacturing sectors.

Figure 8. SMEs perform comparatively well on productivity, but larger firms lag further behind the global frontier

2016

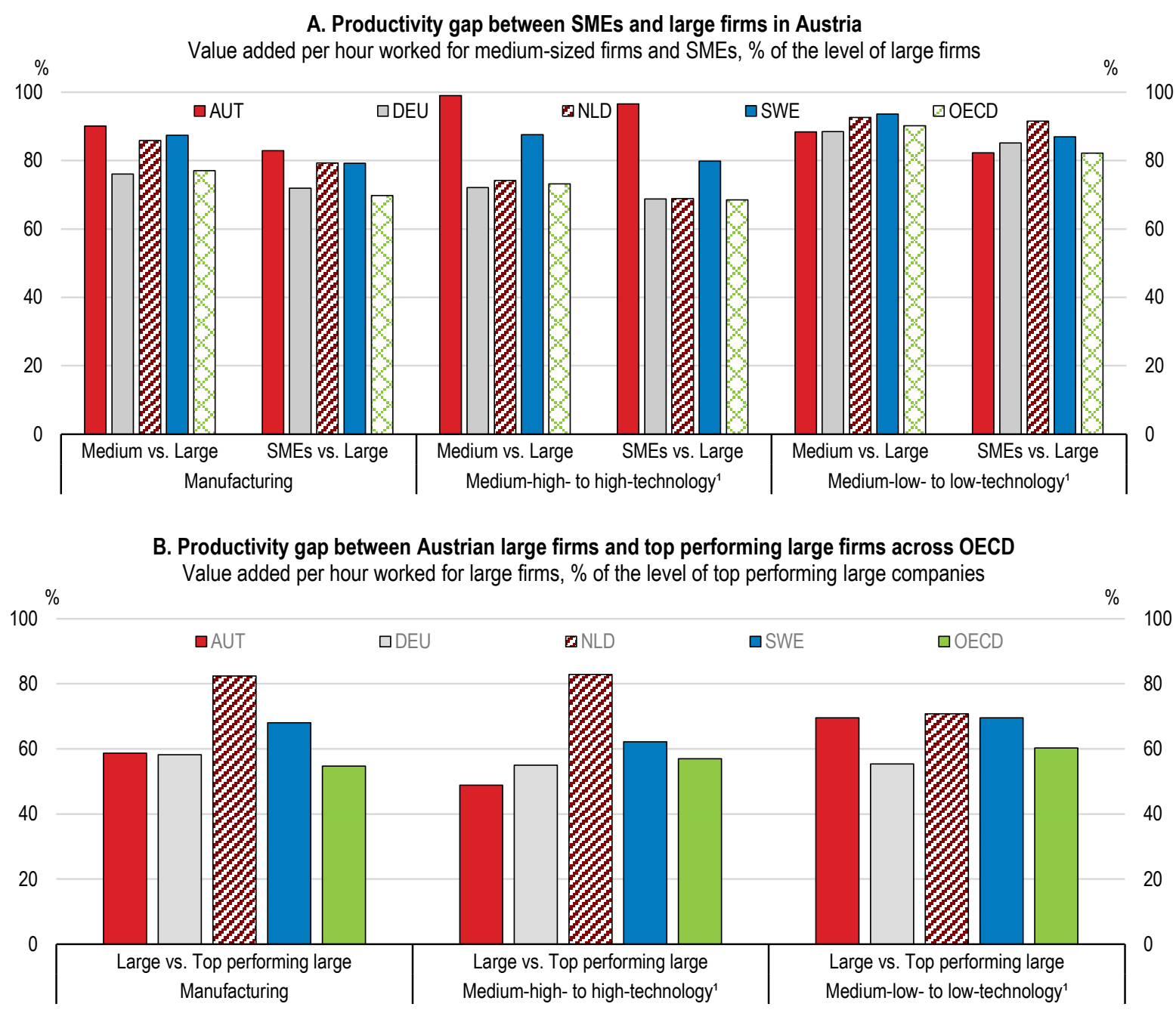

1. It consists of the following NACE Rev.2. sections: (1) medium-high- to high-technology manufacturing sectors refer to the sections $20,21,26$ and 27 to 30, (2) medium-low- to low-technology sectors refer to other manufacturing sections.

2. OECD is the unweighted average of $29 O E C D$ countries.

Source: OECD (2018), OECD Structural Analysis Statistics (database).

\section{Emerging challenges from three mega-trends}

The Austrian economy faces emerging challenges from three trends. First, ageing will put downward pressure on the size of the working age population. Second, new digital technologies will go hand in hand with disruptions that may change production processes or services fundamentally. Third, increased fragmentation of goods and services across firms and countries pose opportunities but also challenges to the business universe. 
The shrinking of the working age population in Austria, projected to fall by $14 \%$ until 2050 (Figure 9), will be a major challenge to employers. As SMEs typically focus more on day-to-day running of the business and may lack the resource for searching extensively for available talent (Hellman and Kavadia, 2016), skill shortages constrain SMEs more than large firms. More than eight out of ten Austrian SMEs, an increase of 18 percentage points compared to year before, consider already today the lack of talent a major impediment to upscaling through investment, which is above the EU average (EIB, 2018). The ageing of Austrian society will further aggravate the skill constraint. Moreover, many current owner-managers of today's SMEs are reaching their retirement age. Nearly one-third of all privately held Austrian enterprises, accounting for $30 \%$ of total employment, will be up for ownership transmission by 2023 (Zieniel et al., 2014). Business transfers constitute a critical stage in the lifecycle of a company. Unsuccessful transmission of otherwise vibrant firms may have detrimental effects on employment and productivity. Yet, demographics may provide the necessary pressure and window of opportunity to integrate today's disadvantaged groups, such as high-skilled migrants, women, younger and older people and people with handicaps, into the labour force thereby contributing positively to a more inclusive society.

\section{Figure 9. Demographic change reduces the size of Austria's talent pool}

Projected change in working age population (15-64 year-olds), 2020-2050

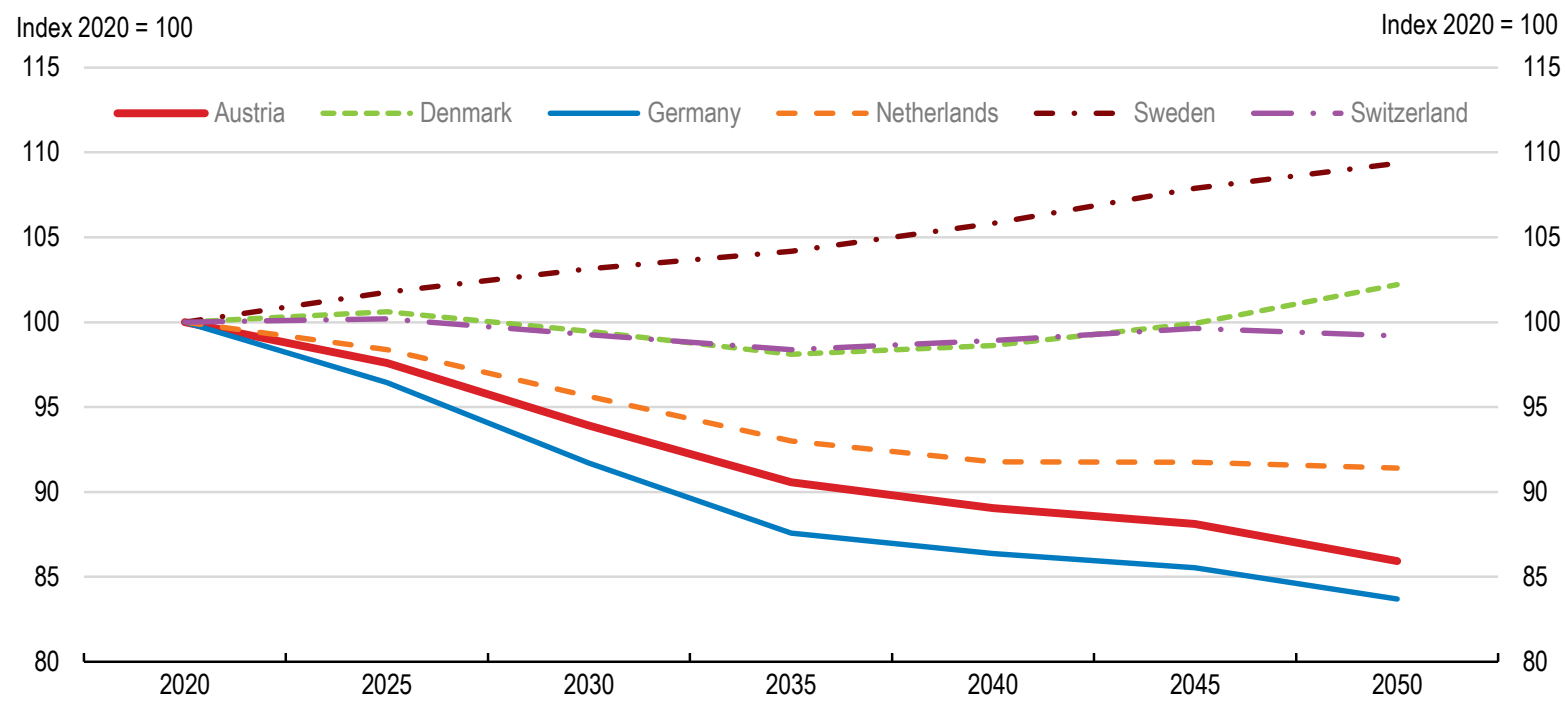

Source: United Nations (2018), World Population Prospects.

New digital technologies are changing the ways in which firms pursue business activities and interact with customers and clients. Since the decreasing costs of these technologies enable a wide diffusion, businesses can reach out more easily to new markets and customers (OECD, 2017c). They can also improve productivity through improved access to up-to-date information, technology and applications. Moreover, some technologies, especially artificial intelligence bundled with the availability of massive amounts of data, have the potential to act as "game-changers", i.e. creating entirely new business applications and models (OECD, 2018c). Moreover, access to cloud-computing may allow SMEs to access to digital solutions independent of firm size and lead to increased employment and productivity for young firms (DeStefano, Kneller, and Timmis, 2019). Potentially, the digital revolution can thus even counterbalance the advantages of large companies in terms of returns to scale and blur the distinction between SMEs and large companies. 
However, due to returns to scale and network effects, the digital revolution increases the potential for "winner takes it all" dynamics. Since digital technologies enable better access to worldwide customers and suppliers, they increase international competition. The increased use of digital technologies will also likely pose challenges for the management of small- and medium-sized companies. Successful adoption of new ICT applications require the managerial capital to use these technologies effectively. In addition, the digital transformation also poses additional challenges for SME enterprises. With more devices connected to the internet and increased use of ICT, businesses face greater risks from cybercrime and other digital threats. Due to returns to scale in ensuring digital security, SMEs are more vulnerable and in particular need to improve their digital security risk management practices (OECD, 2017).

Austria is highly integrated in global value chains. Austria's economy relies significantly more on foreign intermediate goods than other countries on Austria's inputs (OECD, 2017b). Austrian SME enterprises in manufacturing sectors are more likely to export and medium-sized companies in Austria contribute more to total exports than in peer countries and the OECD average (Box 1). The high share of SMEs competing on international markets poses opportunities but also challenges. Increased engagement in export activities can help SMEs to scale up faster through tapping new markets. Exposure to international markets can further be beneficial for productivity through increased competition, improved access to cheaper goods and spill-overs of technology and managerial know-how (Lopez-Gonzalez, 2017). However, since more Austrian SMEs export than elsewhere, the Austrian economy is also more exposed to the downside risks of globalisation. As other countries, in particular from the CESEE region, upskill and move up the quality ladder, their products are increasingly competing with Austrian products (Belka et al., 2016). Moreover, SMEs are more vulnerable to the effects of trade barriers, as, inter alia, they are much less likely to influence trade policy processes (Fliess and Busquets, 2006) and incur additional costs with detrimental consequences on their competitiveness (Requena-Silvente, 2005).

\section{Firming up the capital structure of the Austrian business sector}

Total business investment as a share of GDP has recovered from the Great Financial Crisis and surpassed its pre-crisis level (Figure 10, Panel A). Business investment has been a key driver of the ongoing expansion (Ederer, 2018). The composition of total investment shows that expenditures for intangibles, such as investment in intellectual products like R\&D spending, patents, software, have risen, gradually increasing their share in total business investment from 13\% in 2000 to $21 \%$ in 2017 (Figure 10, Panel B). This increase is in line with rising shares of intangible investments across OECD countries (Rouzet and Eberly, 2018; OECD, 2018) and underlines the pace of the ongoing transformation towards a knowledge economy. However, data from national accounts on intangible investment have to be interpreted with care. Investment in intangibles often requires expenditures for enabling the use of intangibles, which can be much larger than the initial investment. Such additional investments, for instance training existing staff, however, are not counted in national account data. The relevance of intangibles is therefore likely underestimated (OECD, 2018). 
Figure 10. Business investment is above pre-crisis levels with shift towards intangibles

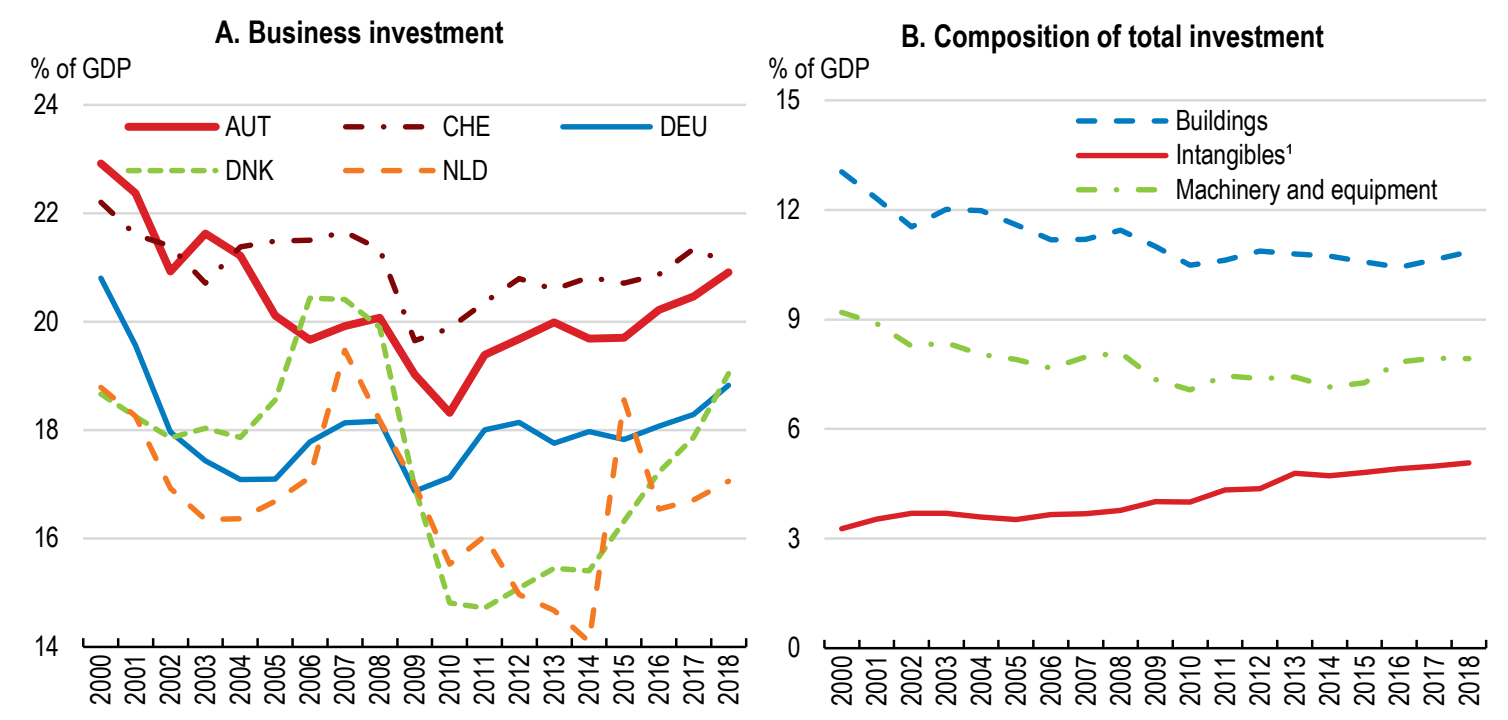

1. Intellectual property includes R\&D, computer software and databases; mineral exploration and evaluation; and entertainment, literary or artistic originals and other intellectual property products.

Source: OECD (2019), OECD Economic Outlook: Statistics and Projections (database) and OECD National Accounts Statistics (database).

The growing importance of intangibles poses challenges for the composition between debt and equity. While financial development in general tends to benefit economic growth by reducing firms' costs of external capital (Rajan and Zingales, 1998), equity and credit markets tend to play different roles in fostering investment in intangibles. Intangibles investment are more difficult to value, because they tend to be partly embedded in human capital. Additionally, information on business success of new technologies without a track history is likely to be sparse. Therefore, intangible investments are more difficult to use as collateral (Hall and Lerner, 2010). Further, young firms in high-tech sectors, which are likely to experiment with these new technologies and foster their diffusion, have more uncertain and skewed returns (Brown, Fazzari, and Petersen, 2009), restricting the use of credit. By contrast, equity investors share the full upside returns and require no collateral requirements. Moreover, additional equity does not increase the probability of default (Hsu, Tian, and Xu, 2014). Empirical evidence underscores that external finance through equity benefits innovative activity, especially in high-tech sectors (Brown, Martinsson, and Petersen, 2012; Hsu, Tian, and Xu, 2014).

These challenges may be more demanding for a traditional bank finance model like Austria's. Banks may not have the right expertise to evaluate projects without track history. The emphasis on collateral to back up the ability to meet financial obligations limits funding to new firms and already highly leveraged firms. However, the Austrian system of bank financing relies on relationship banking, the so-called Hausbank system, and may mitigate some of the disadvantages of the strong focus on bank loans. Due to close relationship between bankers and business owner, Austrian bankers have access to more and better information, especially on private assets of company owners (Dirschmid and Waschiczek, 2005), therefore making it easier for firms of all sizes to borrow funds. Additionally, the Hausbank shows a greater willingness to continue to support firms with funds in financially difficult situations (Dirschmid and Waschiczek, 2005), which helps to smooth the business cycle, but may also increase the risk of capital getting trapped in zombie firms (McGowan, Andrews and Millot, 2017). Thus, a bank loan from the Hausbank may take up some of the functions equity capital provides in other countries (Dirschmid and Waschiczek, 2005). 
According to various surveys, access to finance for Austrian firms tends to be good. Only $2 \%$ of Austrian firms consider themselves as constrained by their access to finance, below the EU average of $5 \%$ (EIB, 2018).According to the latest SAFE survey of the ECB, access to external sources of finance further improved over the 6 months from October 2018 to March 2019 and increased more than investment needs (ECB, 2019). Austrian firms tend to be satisfied with the amount of external finance received, including defining characteristics, like interest rates and maturity. However, $10 \%$ of Austrian businesses, compared to $6 \%$ for the EU average, see the required collateral as too high (EIB, 2018). Further, $67 \%$ of Austrian firms report that they prefer to rely on internal sources, which is above the EU average of $62 \%$. While internal financing ensures that less information has to be disclosed with outsiders, it also implies that firms hold back investments when the economy is contracting.

\section{The capital structure is biased towards debt-financing}

The composition between debt and equity of an economy can be evaluated by looking at its aggregate capital structure. Austria has one of the highest debt-to-equity ${ }^{1}$ ratios among OECD countries (Figure 11, Panel A) but a moderate level of total leverage, as compared to the OECD average (Figure 11, Panel B). This reflects very low provision of equity capital and a strong focus on bank financing. A simple comparison illustrates this further: while the level of leverage of non-financial corporations in Denmark is significantly higher than in Austria, the aggregate debt-to-equity ratio in Denmark is only $70 \%$ of that in Austria.

\section{Figure 11. High debt-to-equity ratios but moderate total leverage point to lack of equity capital}

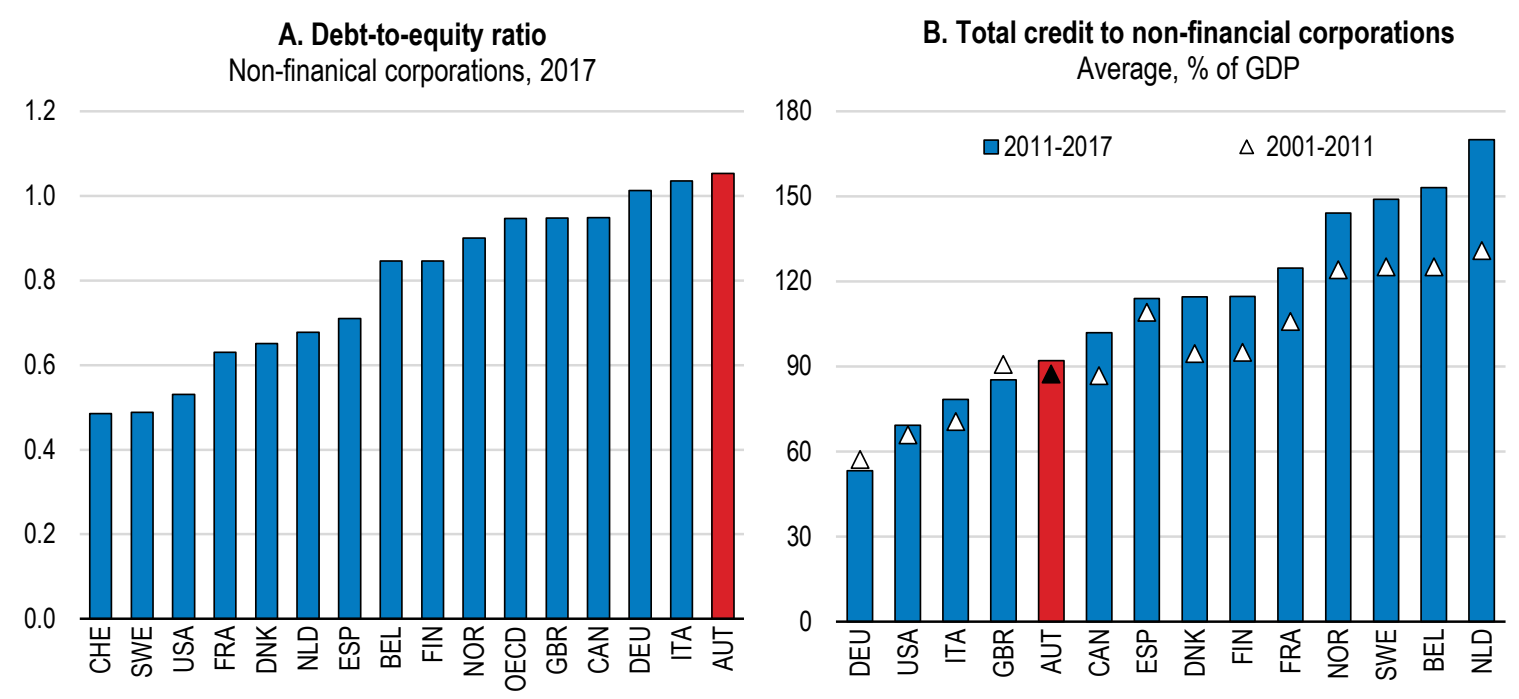

Source: OECD (2018), OECD Financial Dashboard and BIS International Debt Securities Statistics 
Figure 12. High capital intensity and prevalence of family-owned enterprises lead to high debt-toequity ratios in tourism industries

Debt-to-equity ratios and capital intensity by sector, 2016

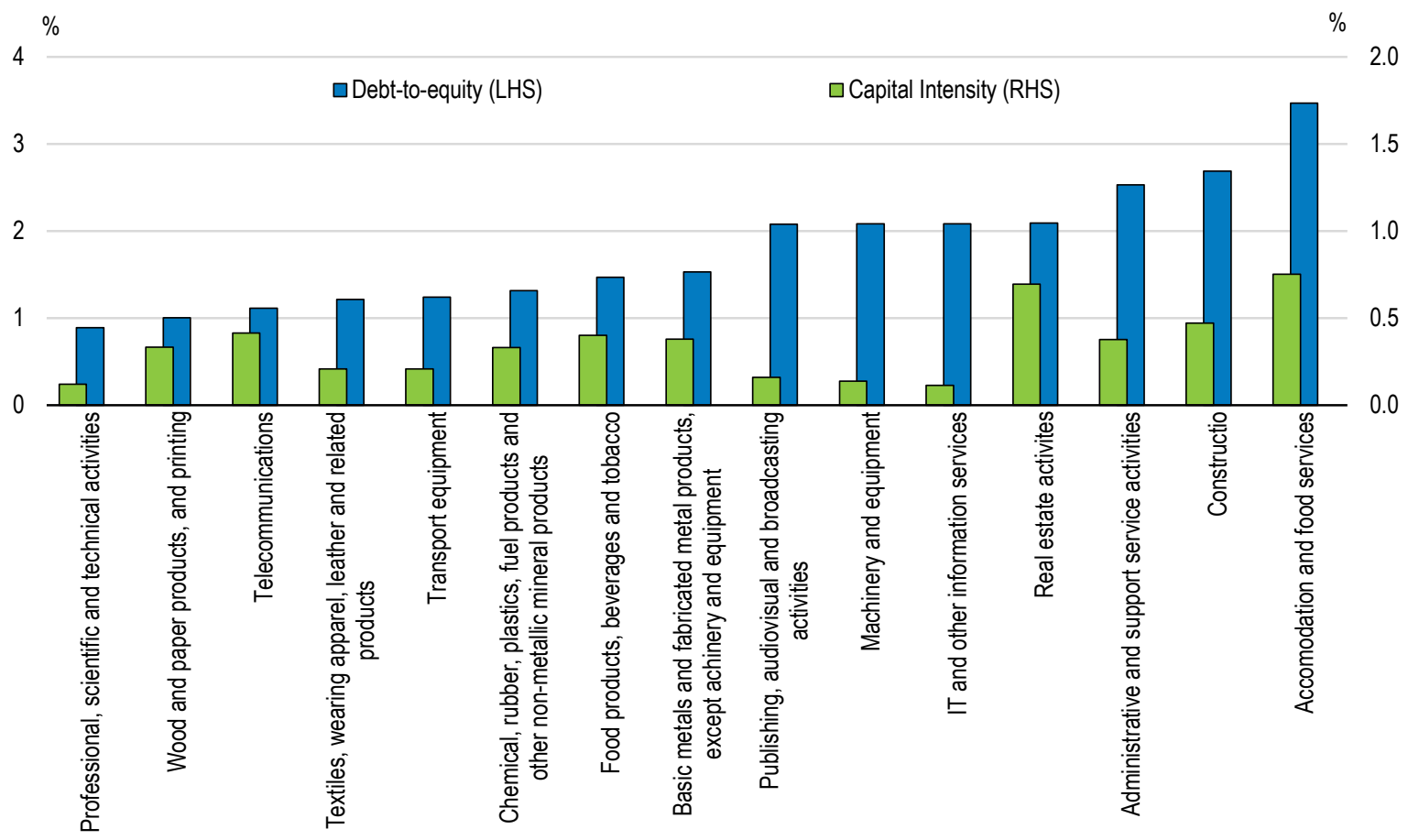

Note: Based on NACE rev.2. Capital intensity is calculated as the share of fixed assets over total assets.

Source: Bank for the Accounts of Companies Harmonized (BACH) database.

A more granular perspective on Austria's debt-to-equity ratio reveals that firms in the tourism sector ("Food and accommodation services") have a high debt exposure, followed by those in construction sectors (see Figure 12). The variation in the debt-to-equity ratio across sectors can only partly be explained by differences in the share of fixed assets employed. Furthermore, high debt-to-equity ratios in the tourism sector are also due to the high prevalence of family-owned enterprises (WKO, 2018). Family-owned enterprises tend to be averse to losing control to family outsiders and therefore have additional incentives to take on debt instead of equity in order to continue to maintain their controlling power (González et al., 2013). 


\section{Figure 13. Debt-to-equity ratios of Austrian SMEs are higher than in peer countries}

Debt-to-equity ratios and total leverage in manufacturing and business services, 2016
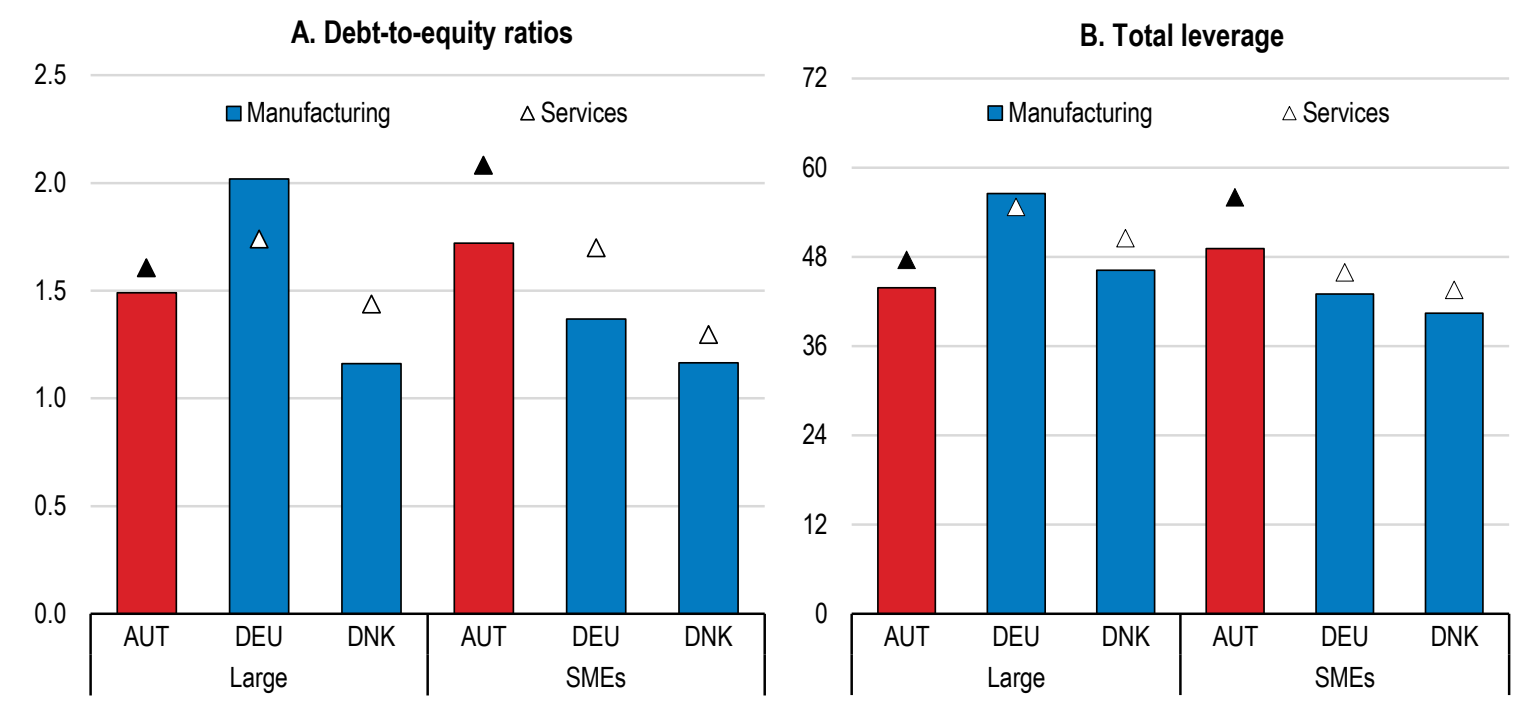

Note: Based on NACE rev.2. Services refer to business services excluding finance, insurance and real estate.

Source: Bank for the Accounts of Companies Harmonized (BACH) database.

Debt-to-equity ratios of Austrian small- and medium-sized enterprises are higher than in Germany and Denmark, peer countries with available data (Figure 13, Panel A and B). This goes hand in hand with higher total leverage for small- and medium-sized enterprises than in peer countries. However, a back of the envelope calculation shows, that even with the lower leverage level of peer countries (for example Denmark), Austrian small- and medium sized enterprises would still have a $22-30 \%$ higher debt-to-equity ratio, suggesting that more equity capital would be needed to achieve a lower debt-to-equity ratio.

Austrian firms have relatively high debt-to-equity ratios, though only partly explained by the levels of total leverage. It is still meaningful to have a closer look at the supply of credit for two main reasons. First, leverage above a certain threshold can constrain investments in tangible assets and economic growth (Cournède and Denk, 2015), because fewer internal resources are available for capacity expansion. Moreover, access to external credit becomes more difficult at higher levels of leverage due to higher default risks (Aivazian, Ge, and Qiu, 2005). Second, small- and medium-sized enterprises are more vulnerable to credit tightening (OECD, 2012) and banks usually decrease loans to SMEs faster than for large firms (ECB, 2013). 
Figure 14. Bank loans are the most important form of external credit for small- and medium-sized firms

Business sector, 2016

\section{A. Composition of debt}

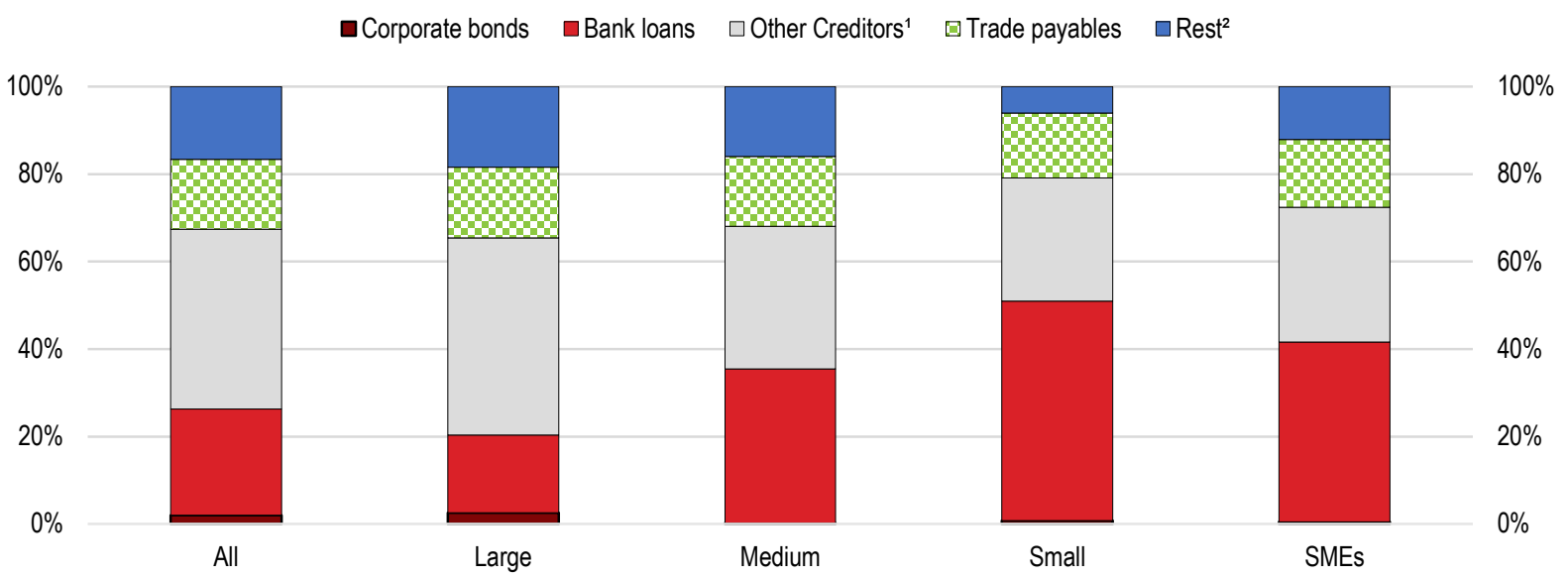

B.Share of bank loans

$\%$ of total debt

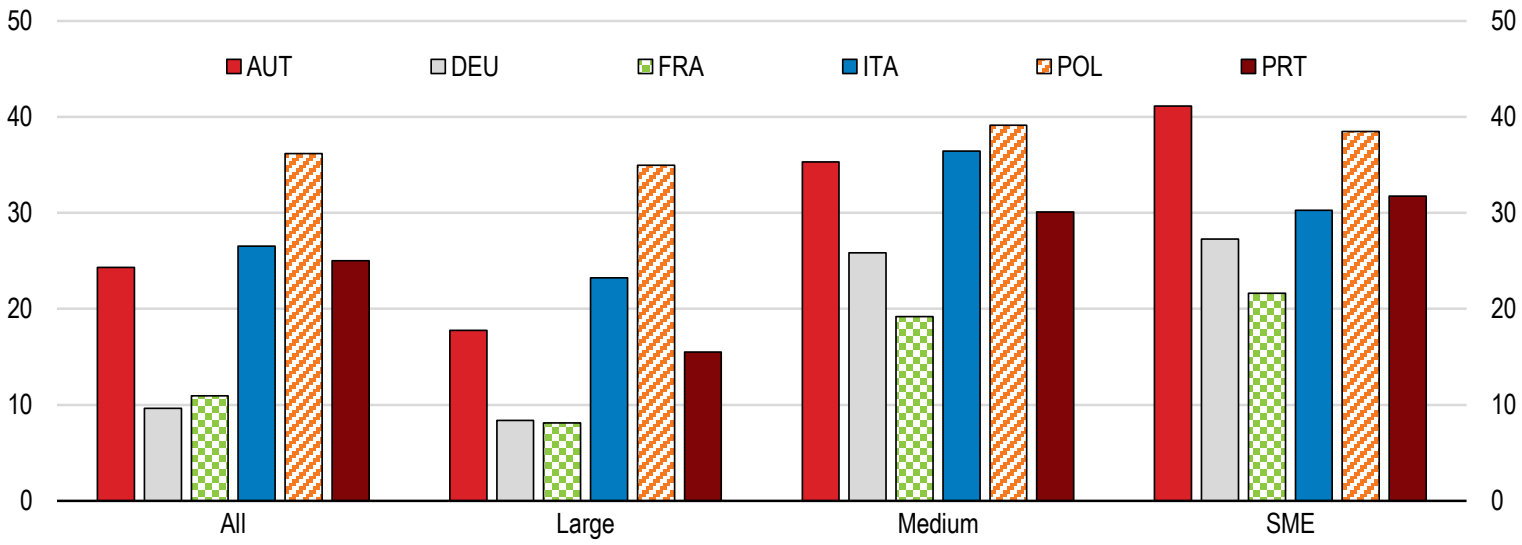

1. Other creditors include intra-group debt, accounts payables (except trade payables and payables to other financial creditors), mainly tax and social security payables, staff debt and active dividends to be paid. Rest includes payments received on account of orders and deferred liabilities. 2. Rest includes payments received on account of orders and deferred liabilities.

Source: Bank for the Accounts of Companies Harmonized (BACH) database.

Bank loans are the main source of external credit for Austrian small- and medium-sized enterprises (Figure 14, Panel A). The amount of bank loans used for finance correlates negatively with the size of enterprises. Bank loans in small firms in business sectors make up $50 \%$ of total leverage, but only $18 \%$ in large firms. In comparison with other European countries with available data, Austrian firms make more use of bank financing, in particular in small- and medium-sized companies (Figure 14, Panel B). Other important forms of leverage include trade payables and loans from other creditors, including intra-group debt. The use of trade payables in Austrian manufacturing sectors make up around $16 \%$ of all external financing and is roughly constant across firm sizes. However, the comparison with European countries with available data suggests that trade payables are less important in Austria. 
The availability of bank credit to Austrian firms of all sizes is high. On average, Austria SMEs pay a premium of 0.38 bps over interest rates charged by banks to large firms, which is relatively low compared to peer countries (Gassler, Pointner and Ritzberger-Grünwald, 2018). Only 1\% of SME loan application were actually rejected (Gassler, Pointner and Ritzberger-Grünwald, 2018). Further, the share of non-performing loans of all firms have been decreasing and stood at 3.1\% in 2016 (OECD, 2018b). The high access to bank loans of Austrian SMEs reflects various guarantees and support programs of the Austrian development bank, Austria Wirtschaftsservice $\mathrm{GmbH}$ (aws), bundled with initiatives that foster SME financing at the level of the European Union. In 2016, around $78 \%$ of all guarantees of the government were granted by aws, which guarantees up to $80 \%$ of the total loan amount.

New analysis for this Survey based on micro-level data of Austria firms using the Orbis database, suggests that high debt capital tends to be associated with less investment (Box 2). In particular, marginal increases to the level of long-term debt are negatively correlated with firm-level investment. The empirical framework takes the potential endogeneity between investment and debt into account by using an empirical strategy based on instrumental variables.

\section{Box 2. Long-term debt reduces growth opportunities of small- and medium-sized enterprise more than of large firms}

\section{The firm-level data}

The analysis uses micro-level data on Austrian firms from the Orbis database. Orbis provides annual balance-sheet data for listed and non-listed firms. While the coverage of Austrian firms may differ from a representative sample of the Austrian firm universe, it is nevertheless the only firm-level database currently available for listed and non-listed Austrian firms with combined data on financial and economic variables. In this respect, the recent reforms of Statistik Austria should not further restrict the access of Austrian and external researchers to Austrian micro-level data. Instead, micro-level data should be made similar accessible to researchers like in Germany, Denmark or Netherlands, which would contribute to the understanding of the Austrian economy at a granular level.

The data in this analysis relies on all Austrian firms in manufacturing industries in the 2011-2016 period.

\section{Modelling investment}

The aim is to examine the impact of long-term leverage levels on investment. Total investment is modelled in a dynamic framework. Further, the model controls for lagged cash holdings, i.e. takes source of internal financing into account. The firms' demand situation is captured through firms' sales. In order to incorporate the firm specific demand for investment goods, the analysis includes the level of the capital stock and output, equivalent to the standard error-correction formulation in the investment literature (e.g. Bond et al. (2003); Buca and Vermeulen (2017)). The key variable of interest is the level of long-term debt. However, the level of debt in an investment model is likely endogenous, if investment is - at least partially - financed by debt. Since the investment model also controls for all unobserved time-invariant drivers of investment at the firm-level, the lagged dependent variable suffers from correlation with the error term and is therefore biased (Nickell, 1981). The analysis in this chapter deals with this two-fold problem by using internal instruments in a difference GMM estimation framework. The statistical diagnostics underlying the validity of the difference GMM estimation are shown in the table below. They are discussed in detail in Dlugosch and Gul (forthcoming).

In addition, the analysis controls for shocks common to all firms using a non-parametric time control, i.e. dummy variables for each year. 


\section{High long-term debt impedes investment}

The analysis finds that lagged long-term debt is negatively correlated with investment (Table 1). Importantly, the estimations take the potential endogeneity of investment and debt into account through instrumenting debt with lagged values. The estimated coefficients illustrate the ceteris paribus effect of an increase of long-term debt on the capacity to undertake investment in the next year. Therefore, the results suggest that higher levels of debt, other things equal, tends to discourage further firm-level investment.

Given that Orbis does not cover the total Austrian firm universe, these estimates need to be interpreted with care. As a robustness check, the analysis also re-estimates the investment model based on data from the BACH database. The BACH database provides annual balance-sheet data of non-financial companies aggregated at the industry level. The estimation sample consists of all Austrian non-financial industries in the 2000-2016 period. The estimations based on this different data source confirm that higher leverage is associated with lower fixed investment for Austrian non-financial industries. Further details on the $\mathrm{BACH}$ dataset, estimations using $\mathrm{BACH}$ data and tabulated results can be found in Dlugosch and Gul (forthcoming).

\section{Table 1. Firm-level regression results}

\begin{tabular}{|c|c|c|c|c|}
\hline & $(1)$ & $(2)$ & (3) & (4) \\
\hline \multicolumn{5}{|l|}{$\begin{array}{l}\text { Dependent variable: } \\
\text { Investment (t) / Capital(t-1) }\end{array}$} \\
\hline \multirow[t]{2}{*}{ Investment (t-1) / Capital(t-2) } & $-0.4328^{* * *}$ & $0.3174^{* \star *}$ & -0.1865 & -0.1021 \\
\hline & $(0.0205)$ & $(0.0137)$ & $(0.1758)$ & $(0.1426)$ \\
\hline \multirow[t]{2}{*}{ Ln(Output(t-2)/Capital(t-2)) } & $-0.3329^{* * *}$ & $-0.0302^{* * *}$ & $-0.0384^{*}$ & $-0.0480^{* * *}$ \\
\hline & $(0.0184)$ & $(0.0016)$ & $(0.0223)$ & $(0.0181)$ \\
\hline \multirow[t]{2}{*}{$\operatorname{Cash}(\mathrm{t}-1) / \mathrm{K}(\mathrm{t}-2)$} & 0.0002 & $-0.0009^{*}$ & -0.0021 & -0.0026 \\
\hline & $(0.0014)$ & $(0.0004)$ & $(0.0028)$ & $(0.0023)$ \\
\hline \multirow[t]{2}{*}{ Output growth (t) } & $0.1043^{* * *}$ & $0.0523^{* * *}$ & 0.0084 & 0.0259 \\
\hline & $(0.0095)$ & $(0.0067)$ & $(0.0483)$ & $(0.0349)$ \\
\hline \multirow[t]{2}{*}{ Output growth (t-1) } & $0.2470^{\star \star *}$ & $0.0655^{\star * *}$ & $0.0563^{\star *}$ & $0.0718^{* * *}$ \\
\hline & $(0.0149)$ & $(0.0070)$ & $(0.0267)$ & $(0.0201)$ \\
\hline \multirow[t]{2}{*}{ Total debt (t-1)/Capital(t-2) } & 0.0001 & $-0.0001^{* *}$ & $-0.0001^{* \star}$ & $-0.0001^{* * *}$ \\
\hline & $(0.0001)$ & $(0.0000)$ & $(0.0000)$ & $(0.0000)$ \\
\hline \multirow[t]{2}{*}{ Employment growth)t-1) } & & & & $0.0681^{*}$ \\
\hline & & & & $(0.0386)$ \\
\hline \multirow[t]{2}{*}{ Constant } & $0.1554^{* * *}$ & $0.1287^{* * *}$ & $0.1793^{* * *}$ & $0.1608^{* * *}$ \\
\hline & $(0.0137)$ & $(0.0117)$ & $(0.0297)$ & $(0.0237)$ \\
\hline Observations & 4,664 & 4,664 & 4,664 & 4,664 \\
\hline R-squared & 0.2081 & 0.2406 & & \\
\hline Number of id_i & 2,459 & & 2,459 & 2,459 \\
\hline \# of instruments & & . & 44 & 54 \\
\hline $\mathrm{AR}(1)$ & 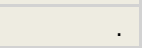 & . & 0.0893 & 0.0130 \\
\hline $\operatorname{AR}(2)$ & . & . & 0.374 & 0.569 \\
\hline Hansen $p$ & & . & 0.743 & 0.763 \\
\hline
\end{tabular}

Note: Robust standard errors in parentheses. ${ }^{* * *} p<0.01,{ }^{* *} p<0.05,{ }^{*} p<0.10$

Source: OECD calculations. 
There is little scope for policies to foster investment by further stimulating the provision of debt capital. Evidence from investment surveys underpins that access to external finance through debt is sufficient. The empirical analysis suggests that marginal increases in long-term debt would decrease investment. Additionally, the digital revolution goes hand in hand with the emergence of knowledge-based economies where investment in intangibles takes on a much more prominent role. However, intangibles are more difficult to pledge as collateral (Hsu et al., 2014), thereby restricting the use of bank-based loan financing. Thus, the relatively strong credit markets in Austria need to be complemented with other forms of financing in order to enable Austrian firms to adopt and experiment with these new technologies. Austrian policies in this area have to comply with EU capital market rules and regulations, but there is room for various national initiatives to support the equity ecosystem, for example by upgrading the financial literacy and the relevant technical know-how of equity issuers and equity investors, and promoting corporate governance and reporting practices improving the information and protection of minority investors.

Strong credit markets should not be seen as a detriment to innovative activity. Indeed, larger established firms tend to benefit from good access to bank financing (Kerr and Nanda, 2015; Mann, 2018). Welldeveloped credit markets may also provide external debt financing to younger firms and start-up, although not directly by lending to the firm but by granting personal credits to the owner (Robb and Robinson, 2014). Here, the Hausbank system may be considered as a strength of the Austrian economy. However, high debt-to-equity ratios but relatively moderate levels of leverage suggest that there is ample room for equity instruments in Austria. Thus, equity and debt markets should be perceived as complementary, rather than mutually exclusive.

Though Austrian businesses make little use of externally raised equity capital, $67 \%$ of Austrian firms state that their preferred source of financing are based on internal sources, which is above the EU average of $62 \%$ (EIB, 2018). According to OeNB (2019), the share of internal financing in total financing was indeed $82 \%$ in 2018 , based on (preliminary) financial accounts data. Internal sources constitutes a form of equity capital and consist of retained operating profits but also include the sales of assets and increases in working capital, such as through reductions in the time it takes to convert inventories and outstanding sales into cash-flows. While internal financing ensures that less information has to be disclosed with outsiders, the amount of internal financing is limited. Thus, investments of a larger scale require additionally externally raised capital.

\section{Deeper Austrian equity markets would help support innovation}

The total domestic market capitalization of all listed Austrian companies is one of the lowest across OECD countries (Figure 15, Panel A). This goes hand in hand with very low levels of stock market turnover, a measure of stock market liquidity (Figure 15, Panel B). Low liquidity makes it difficult for domestic and foreign institutional investors to participate in the stock market and is therefore an unattractive feature of the Austrian stock market (Dahlquist and Robertsson, 2001). Furthermore, the Austrian stock market is characterized by low levels of free-floating shares, which constitutes another impediment to the participation of institutional investors. Block-holders control around $55 \%$ of the total market capitalization in Austria, compared to roughly $30 \%$ in peer countries and $8 \%$ in the US. (Dahlquist et al., 2003). 
Figure 15. Austria has the lowest stock market capitalisation in the OECD and the market lacks liquidity
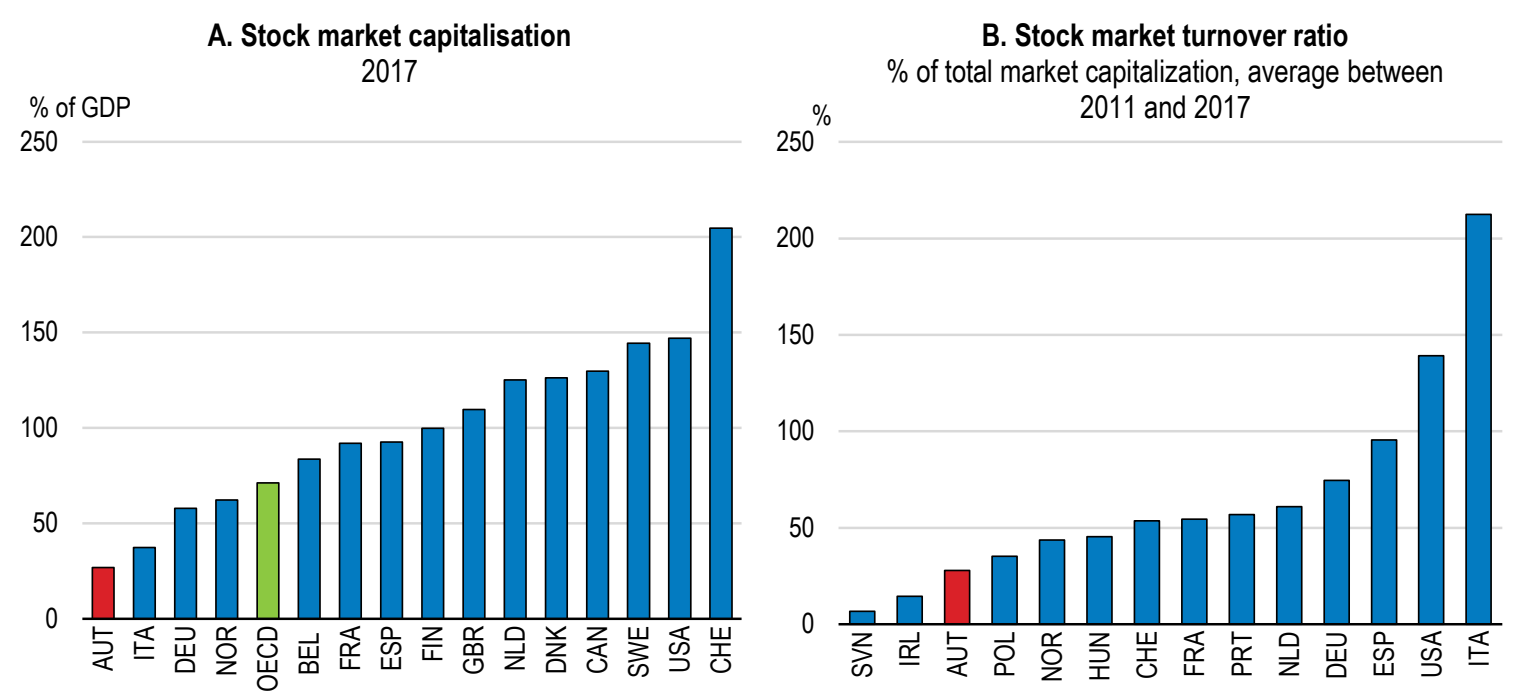

Note: Turnover ratio is calculated as the value of domestic shares traded in a year divided by their market capitalisation.

Source: OECD (2018), OECD Financial Dashboard and World Bank Development Indicators.

The low level of stock market development is in line with a legal framework that emphasizes creditor rights over debtor rights and low disclosure requirements in IPO prospectus and annual reports (Dirschmid and Waschiczek, 2005). Countries that favour debtor rights put a stronger focus on continuing the operation of a company instead of serving creditors. Higher debtor rights and better access to information through more disclosure requirements (LaPorta et al., 2006; Shleifer et al., 2008) are associated positively with firms' equity ratios (LaPorta et al., 1998). However, other countries with strong creditor rights, namely Germany and Denmark, have higher stock market capitalisation over GDP. Thus, the broad legal framework can only partly explain the low levels of Austrian stock market development.

New analysis conducted for this Survey provides evidence that even once size and the legal framework is taken into account, Austria has a rather low number of stock market listing (Box 3 ). This is in line with generally low levels of stock market participation of Austrians (Giannetti and Koskinen, 2010).

\section{Box 3. Is there a listing gap in Austria?}

The share of domestically incorporated companies listed on the Austrian stock exchange, as a proportion of GDP, is low compared to other countries with similar institutions and economic development (Figure 16). Moreover, the ratio has been decreasing steadily, having declined nearly twelve-fold since 1975, and threefold since 2000. The empirical analysis conducted here shows that the number of listed companies per capita in Austria is indeed abnormally low, pointing to the presence of the "listing gap" as compared to other countries with similar institutions and economic development. 


\section{Figure 16. Number of listings per GDP (1 million USD)}

2017

0.0025 0.0025

0.0020

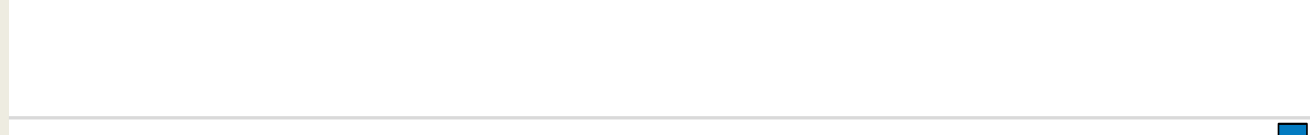

0.0015

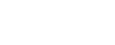

0.0015

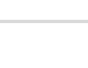

0.0010

0.0005

0.0000

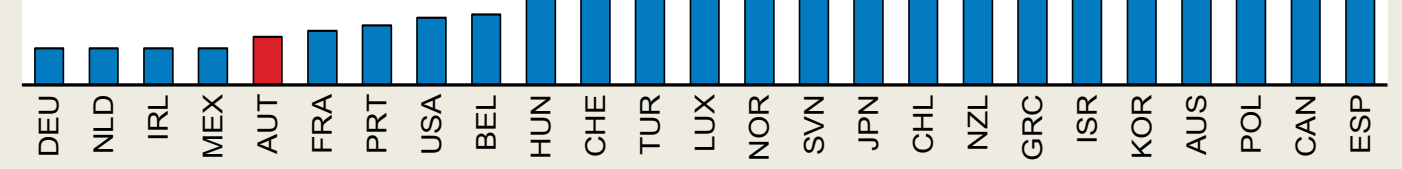

Source: World Bank Development Indicators.

Cross-country regression models allow for an estimation of the expected number of listings per capita, and subsequent count of the listing gap. Previously in the literature, La Porta et al. (1997) projected the number of listed firms per capita on the log of gross domestic product (GDP), GDP growth, a rule of law index, and an index of investor protection. Doidge, Karolyi and Stulz (2017) estimate similar regressions using the log of the average number of listed firms per capita for 1990-2012. After controlling for the log of GDP per capita, they show that listings per capita are strongly positively related to the anti-self-dealing index, a measure of the extent to which related-party transactions are limited in a country.

More specifically, the anti-self-dealing index is a measure of legal protection of minority shareholders against expropriation by corporate insiders. Those who control a corporation, whether they are managers, controlling shareholders, or both, can use their power to divert corporate wealth to themselves rather than sharing it with the other investors. Various forms of such self-dealing include executive perquisites, excessive compensation, transfer pricing, appropriation of corporate opportunities, self-serving financial transactions, such as directed equity issuance or personal loans to insiders, and outright theft of corporate assets (Shleifer and Vishny, 1997). The anti-self-dealing index has been calculated for 72 countries based on legal rules prevailing in 2003. Figure 17 shows more recent data on protection of minority shareholders based on an indicator similar to the self-dealing index from World Bank's Doing Business database. It focuses on private enforcement mechanisms, such as disclosure, approval, and litigation that govern a specific self-dealing transaction, predicting a variety of stock market outcomes. While higher index values indicate better minority protection, Austria's performance is below peer countries. 
Figure 17. Protection of minority shareholder interests across countries

Scale from 0 to 7 (best minority protection), 2017 or 2018

7 7

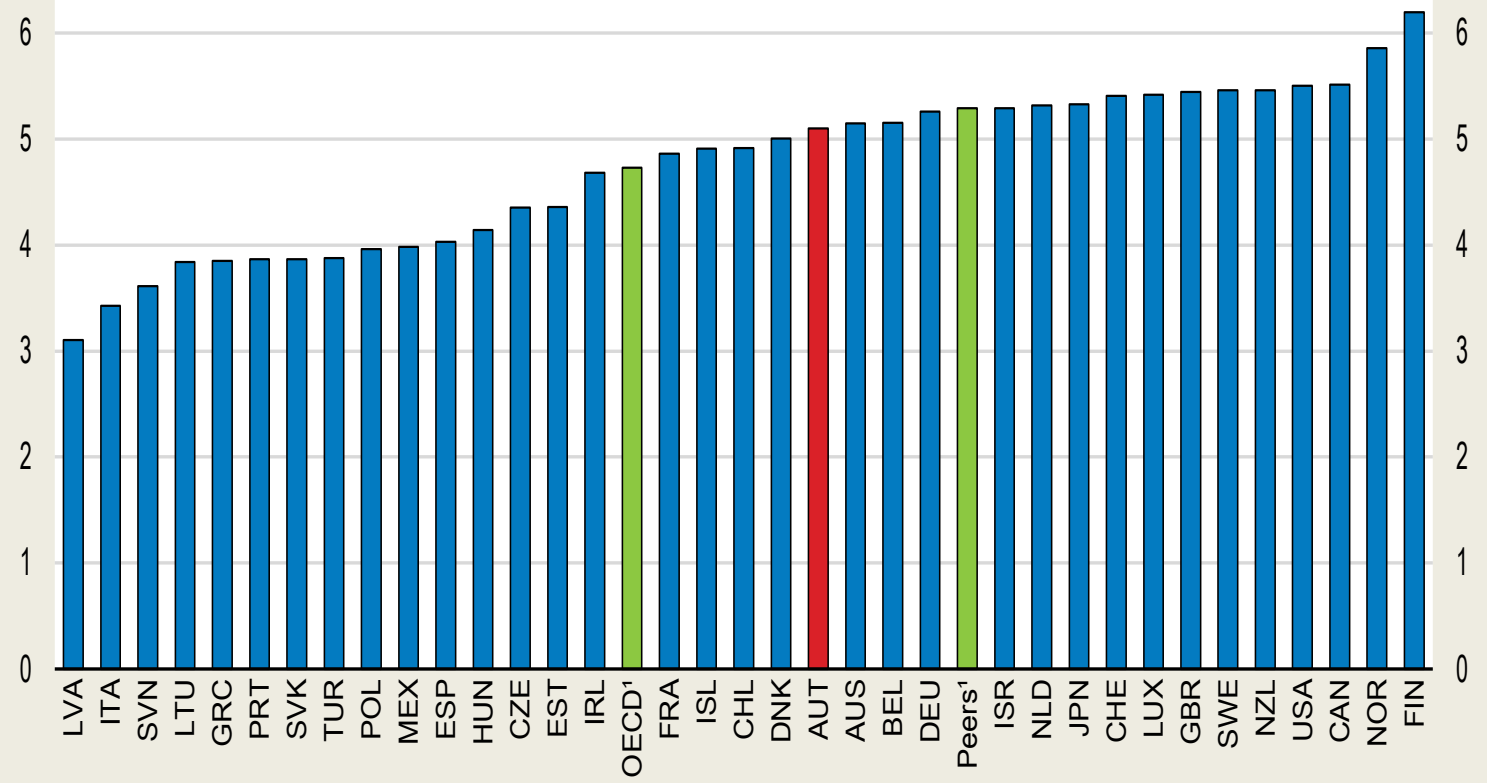

Note: Unweighted average of peer countries. Peer countries include Denmark, Sweden, Germany, Switzerland and the Netherlands. Source: World Bank Doing Business.

The data on the number of listed firms in each country comes from two sources: the World Bank's World Development Indicators (WDI) database and the World Federation of Exchanges (WFE) database, which we merge to create a comprehensive data set. The listings do not include investment companies, mutual funds, real estate investment trusts (REITs), or other collective investment vehicles.

Following Doidge, Karolyi and Stulz (2017), regression of the log of listings per capita on the anti-selfdealing index and on the log of GDP per capita are estimated (Table 2). While the anti-self-dealing index pertains to legal rules in 2003 and may thus appear outdated, we chose to stick to this indicator to better compare results for Austria with the previous literature. In further estimations, we, however, check whether results are robust to using more recent data. Three alternative regressions with additional variables are also considered. In particular, a dummy variable, which takes on the value 0 for Austria, tests whether the number of stock market listings in Austria are significantly different from other countries is introduced. More details on data, estimation and results can be found in the annex.

Consistent with Doidge, Karolyi and Stulz (2017), both the anti-self-dealing index, and GDP per capita have a positive significant coefficient independent on the specification. Models 1 and 2 estimate a crosscountry regression for 2016 , with the latter specification additionally including a non-Austria indicator variable. The non-Austria dummy is indeed highly statistically significant, suggesting a systematic difference between the listings per capita and the explanatory variables for Austria as compared to other countries. The positive coefficient indicates a listing gap in Austria relative to other countries, whose number of listings per capita is significantly higher, given their institutions and economic development. 


\section{Table 2. Institutions, economic development, and listings per capital}

\begin{tabular}{|c|c|c|c|c|}
\hline & \multicolumn{2}{|c|}{ Cross-sectional regressions (2016) } & \multicolumn{2}{|c|}{ Panel regressions (2001-2016) } \\
\hline & (1) & (2) & (3) & (4) \\
\hline \multirow[t]{2}{*}{ log_gdp_cap } & $0.6653^{* * *}$ & $0.6796^{* * *}$ & $0.6532^{\star * *}$ & $0.6532^{\star * \star}$ \\
\hline & $(0.1006)$ & $(0.1024)$ & $(0.0848)$ & $(0.0855)$ \\
\hline \multirow[t]{2}{*}{ anti_sd } & $1.2390^{* *}$ & $1.1671^{*}$ & $1.3995^{* *}$ & $1.3995^{\star *}$ \\
\hline & $(0.5971)$ & $(0.6156)$ & $(0.5358)$ & $(0.5401)$ \\
\hline \multirow[t]{2}{*}{ gdp_growth } & & & -0.0076 & -0.0075 \\
\hline & & & $(0.0218)$ & $(0.0220)$ \\
\hline \multirow[t]{2}{*}{ Non-AUT dummy } & & $0.7035^{\star * *}$ & $0.4191^{*}$ & $0.4715^{\star *}$ \\
\hline & & $(0.2304)$ & $(0.2146)$ & $(0.2200)$ \\
\hline Year FE & & & Yes & Yes \\
\hline \multicolumn{3}{|c|}{ Year FE x non-AUT dummy } & No & Yes \\
\hline Observations & 54 & 54 & 958 & 958 \\
\hline R-squared & 0.4478 & 0.4527 & 0.4526 & 0.4527 \\
\hline Adj. R2 & 0.426 & 0.420 & 0.442 & 0.433 \\
\hline
\end{tabular}

Note: Robust standard errors in parentheses. ${ }^{* *} p<0.01,{ }^{* *} p<0.05,{ }^{*} p<0.10$

Source: OECD calculations.

In the third model, we estimate a panel regression across countries and years for the period 2001-2016. In addition to the variables included in the Model 2, we regress the listings on the GDP growth as an additional variable capturing changing economic conditions. Further, we control for shocks common to all countries by including year fixed effects. As in the previous specification, the non-Austria indicator remains positive and significant.

Finally, Model 4 includes the year fixed effects interacted with the non-Austria indicator variable, allowing for a computation of the Austrian listing gap each year, and to trace its evolution over time. Using the coefficients on the year fixed effects we can compare how actual listings in Austria differ each year from predicted listings, measured relative to the rest of the world (Figure 18). The coefficients for the anti-selfdealing index and GDP per capita remain significant. The adjusted $R^{2}$ is $43 \%$.

Extended models using broader sets of control variables, including liquidity and the provision of debt capital, and importantly more recent data on the protection of minority shareholders do not change the results on the listing gap qualitatively. The annex shows the additional tables and discusses these results in greater detail. 


\section{Figure 18. Estimates of Austria's listing gap}

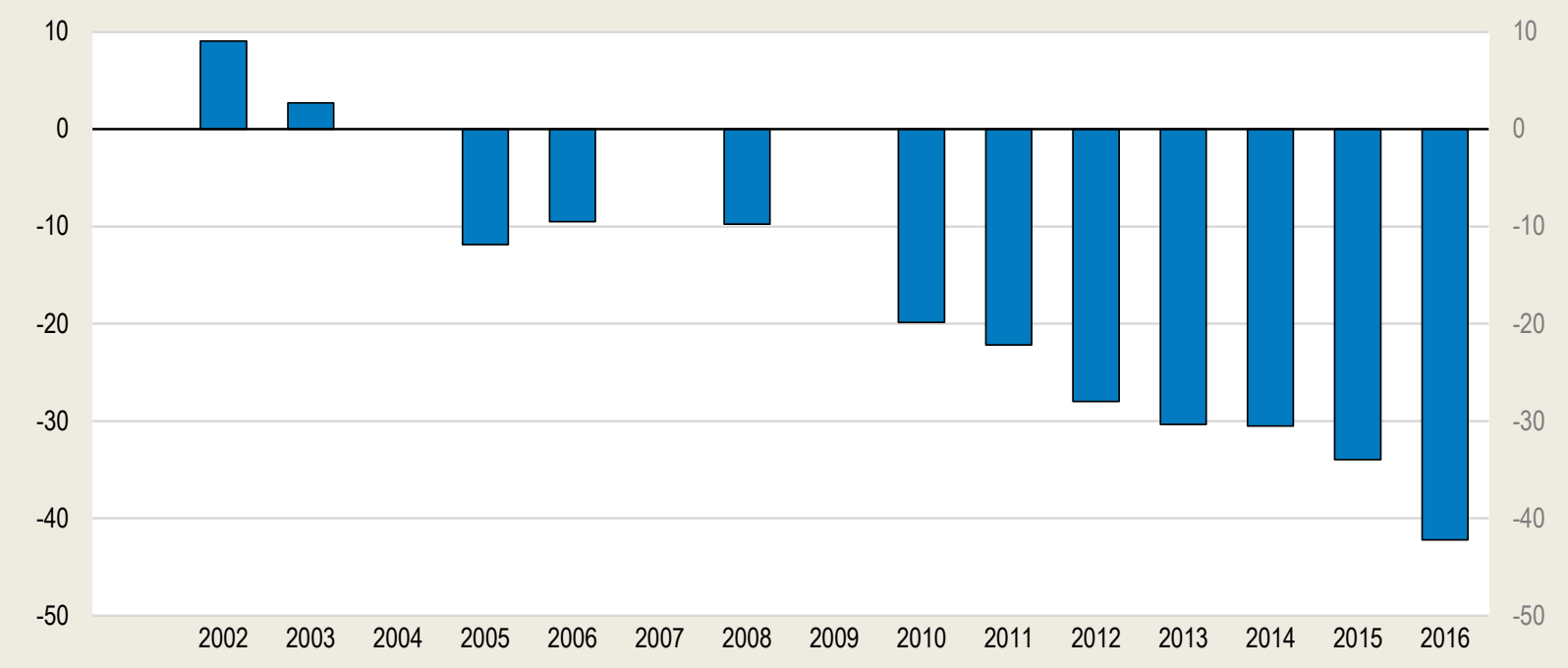

Note: Yearly listing gap was computed using model estimates from Model 4 with the year fixed effect in Table 2.2. Zero values for 2004, 2007 and 2009 reflect estimates which were not statistically significant at the $10 \%$ level.

Source: OECD calculations.

At the beginning of the observed period, the coefficients on the year fixed effects are either statistically insignificant or slightly positive, suggesting an actual overrepresentation of listed firms in Austria, as compared to other countries. The negative gap started appearing from 2005, and has been growing steadily since. As a result, the listing gap reached 42 listings in 2016, with 66 actual listings as compared to 108 expected ones.

The Austrian authorities have already tackled the relatively low development of domestic stock exchange and recently implemented a reform in stock corporation laws geared at easing access for SME firms. Subsequently, the Vienna Stock Exchange has introduced two new segments, which aims at improving access to SME enterprises. These two new segments, "Direct Market" and "Direct Market Plus", operating from 21 January 2019 on, allow small- and medium-sized enterprises to be listed and trade their shares internationally. Austria is, however, late with the introduction of a stock market segment reserved for SMEs as Germany, Spain, France and Italy, among others, have already had such segments in place for more than a decade (Hölzl et al., 2016). First empirical evaluations (Eisele and Nowak, 2017) suggest that the introduction of specific SME segments increased average equity financing by $6 \%$. The better access to capital markets helped to boost investment in tangible capital and decreased SMEs cash holdings, implying that SMEs used less internal financing when access to risk capital improved (Eisele and Nowak, 2017).

The potential economic effects of better access to equity capital on productivity can be sizeable. Demmou and Stefanescu (2018) show that policies aimed at providing similar access to equity and venture capital in Austria as in the average of the Top 5 best-performing OECD countries could lift productivity growth by around $1.5 \%$ pts. annually. The effects are particular pronounced in sectors, which make more use of intangibles, like software, patents, R\&D expenditure but also more human or organizational capital.

However, besides the introduction of two SME segments at the Vienna stock exchange, more efforts are needed to improve the demand and supply of equity capital in Austria. Initiatives at the European level like the Capital Market Union will likely boost the supply of equity capital through more conducive stock market regulations (Raposo and Lehmann, 2019). Nevertheless, domestic policies have room to improve markets 
for risk capital in Austria, either by increasing the demand for equity by firms or by raising the supply of equity by locals. Austria has relatively low levels of stock market participation. According to survey evidence, around $22 \%$ of Austrians hold stocks or mutual funds, in line with neighbouring countries like Germany and Italy, however significantly below the UK (32\%), the Netherlands (34\%) and the US (49\%) (Fessler and Schürz, 2008). The cross-country statistics on stock market participation have to be interpreted with care, as they most rely on self-proclaimed and not observed holdings. Further international time series data is scarce, thus these numbers pertain to the mid-2000s.

Unleashing the full potential of public but also venture and growth capital equity markets requires a vibrant equity eco-system (Nassr and Wehinger, 2016). Such an eco-system comprises institutional investors, investment banks, research analysts, market makers, legal and financial advisors, specialised accountants and other service provides. In order to ensure the success of the new "Direct Market" and "Direct Market Plus" of the Vienna Stock Exchange, the eco-system in particular needs service providers specialised in SMEs (Nassr and Wehinger, 2016).

In this respect, stocktaking of the Austrian capital markets could help to identify potential bottlenecks in the market-based financing eco-system. The stocktaking exercise should include an examination of which firms tap Austrian capital markets, in particular public equity and corporate bond markets, the analysis of more granular data on the current state of capital markets and the structure of the corporate sector would allow to understand the origin and nature of investors, underwriters, intermediaries and other financial service providers. This information can then be used to better identify where Austria's eco-system lags behind and be helpful for designing the right policies to improve companies' access to market-based financing and investor confidence.

The most crucial factor determining the uptake of Austrian stock markets pertains to the general widespread aversion against equity, losing control of entrepreneurs and the aforementioned relatively low participation in stock markets (Hölzl et al., 2016). Here, improving financial literacy can also help entrepreneurs to better understand the benefits of equity capital (OECD, 2018d; Boschman and Pissareva, 2017). Additionally, further equity capital can be obtained without having to share voting rights. This can be achieved for example through hybrid vehicles like preferred stocks.

Stock market participation can be increased through financial literacy (v. Rooij, Lusardi and Alessie, 2011; Boschman and Pissareva, 2017). Results from the OECD/INFE cross-country survey on financial literacy suggests that Austrian have overall slightly above average financial literacy compared to other OECD countries (OECD, 2016b; Cupak et al. 2018). However, there is room for improvement. On the one hand, the beneficial effects of financial literacy on stock market participation tend to be large (v. Rooij, Lusardi and Alessie, 2011). On the other hand, aggregate indexes of financial literacy may mask knowledge gaps in areas directly related to the stock market. Indeed, only $61 \%$ of the 2000 Austrian interviewed in the OECD/INFE survey (OECD, 2016b; Silgoner et al., 2018) correctly grasp the basic notion of diversifying idiosyncratic risk through stock investments, the key concept of modern portfolio theory. This is below the OECD average of $65 \%$. However, the relevant question from the OECD/INFE survey only asks participants whether they are aware of the benefits of diversification and thus do not allow an evaluation of the necessary tools for understanding the benefits of diversification, e.g. correlation and volatility. The Austrian Central Bank actively promotes financial education and initiated a financial education campaign in 2015. However, there is currently no nation-wide strategy for financial education. Such a strategy should foremost tackle financial literacy in a gender- and age-inclusive way, for example by putting financial education on school curricula of all school levels. Moreover, besides basic financial knowledge, financial education should also teach skills related to investments. This is important given that many people actually hold stakes in stock investment, though not always directly, but through the pension system or other financial products like life insurances. Besides changing stock market development and firms' financing possibilities, financial education can also help improve financial decision-making in general with particular positive impacts on retirement savings (Lusardi, 2009). 
Low levels of stock market participation may reflect deep-rooted preferences for less risky assets, i.e. higher degrees of risk aversion. Subsequently, less developed markets for risk capital may constitute the optimal outcome from the viewpoint of households. However, they may also reflect a lack of financial literacy and experience with these products. Revealed preferences from observed financial choices may then overestimate the degree of risk aversion (Heath and Tversky, 1991). A large literature in behavioural economics and finance indeed finds that individuals are prone to systematic biases, which distort their beliefs (Barberis and Thaler, 2003). As empirical evidence suggests that better financial literacy can help to reduce systematic biases and eventually lead to greater risk-taking (Behrman et al., 2012), improving financial literacy still constitutes a way to improve financial decision-making, in particular stock-market participation, even though market outcomes may suggest high degrees of risk aversion.

\section{Addressing the supply of venture and growth capital}

Austrian young firms are very successful in surviving through the first 3 years, though the employment share of these firms is one of the lowest across OECD countries (Figure 19, Panel A and B). On the one hand, this may reflect slow business dynamism and resource allocation (Adalet McGowan, Andrews and Millot, 2017). Firm entry and exit rates in Austria are indeed one of the lowest across OECD countries (Figure 19, Panel C). On the other hand, access to finance and skill shortages may impede upscaling. Young firms tend to have more volatile cash-flows, usually no performance track record and often only few assets which could be used as collateral. This severely restricts their access to bank loans. 
Figure 19. Young firms are successful in surviving the first years but do not grow large

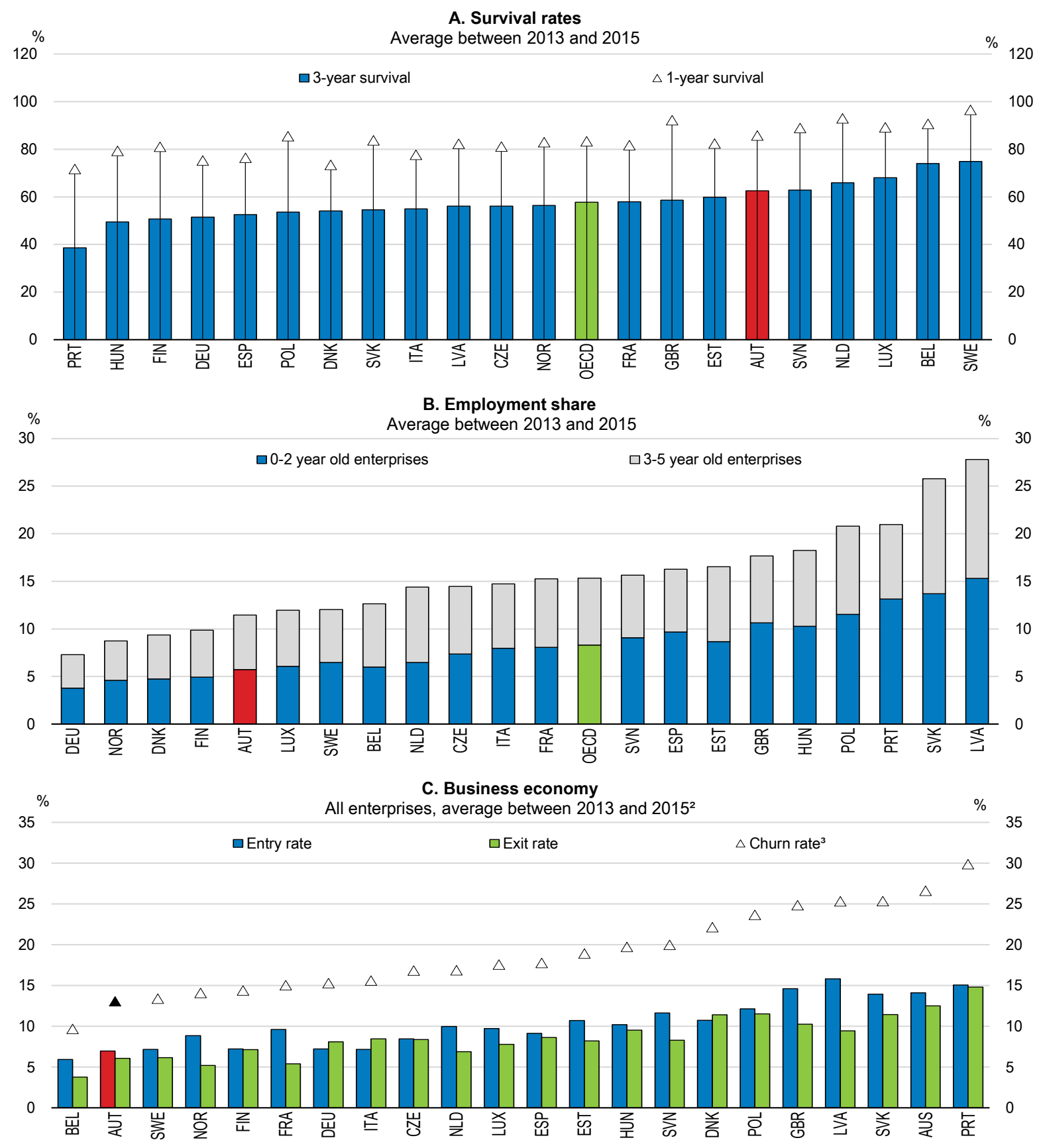

1. Business economy, all enterprises. Data for Denmark refer to 2012-2014.

2. Data for Denmark and Poland refer to 2012-2014.

3. The churn rate is the number of enterprises births and deaths as a percentage of the number of active enterprises.

Source: OECD Structural and Demographic Business Statistics.

Apart from less developed public equity markets, the provision of venture and growth capital in Austria is also low, reflecting a lack of "equity culture". (Figure 20 and Figure 21). Although, this lack of risk capital pertains to other European countries also (AFME, 2017), Austria has less developed venture and growth capital markets compared to countries like Denmark (OECD, 2018d). In 2016, the Austrian authorities launched a new start-up programme with a total volume of around 185 Mio EUR for the next three years, 
which aims at addressing the market failure of low risk financing through providing more risk capital for start-ups and SMEs. This compares roughly to the total amount of venture and growth capital raised in 2017 and illustrates a further key characteristic of Austrian venture and growth markets: Roughly one-half of venture capital funding in Austria is provided through funds from governmental agencies (OECD, 2018d).

Austrian authorities have further enacted the Alternative Financing Act, a measure to facilitate crowdfunding, which entered into force in September 2015. It allows for prospectus-free issuances of certain financing instruments below a certain threshold. In 2018, the Alternative Financing Act was further amended and allows for emissions of investments and securities up to 2 Mio. EUR without having to disclose a prospectus. Instead the issuer has to provide an information sheet. The Alternative Financing Act also contains provisions on investor protection, such as a limit of EUR 5000 per individual investor per issuance.

\section{Figure 20. Venture capital markets lag behind}

Venture capital raised and investments, average between 2013 and 2017

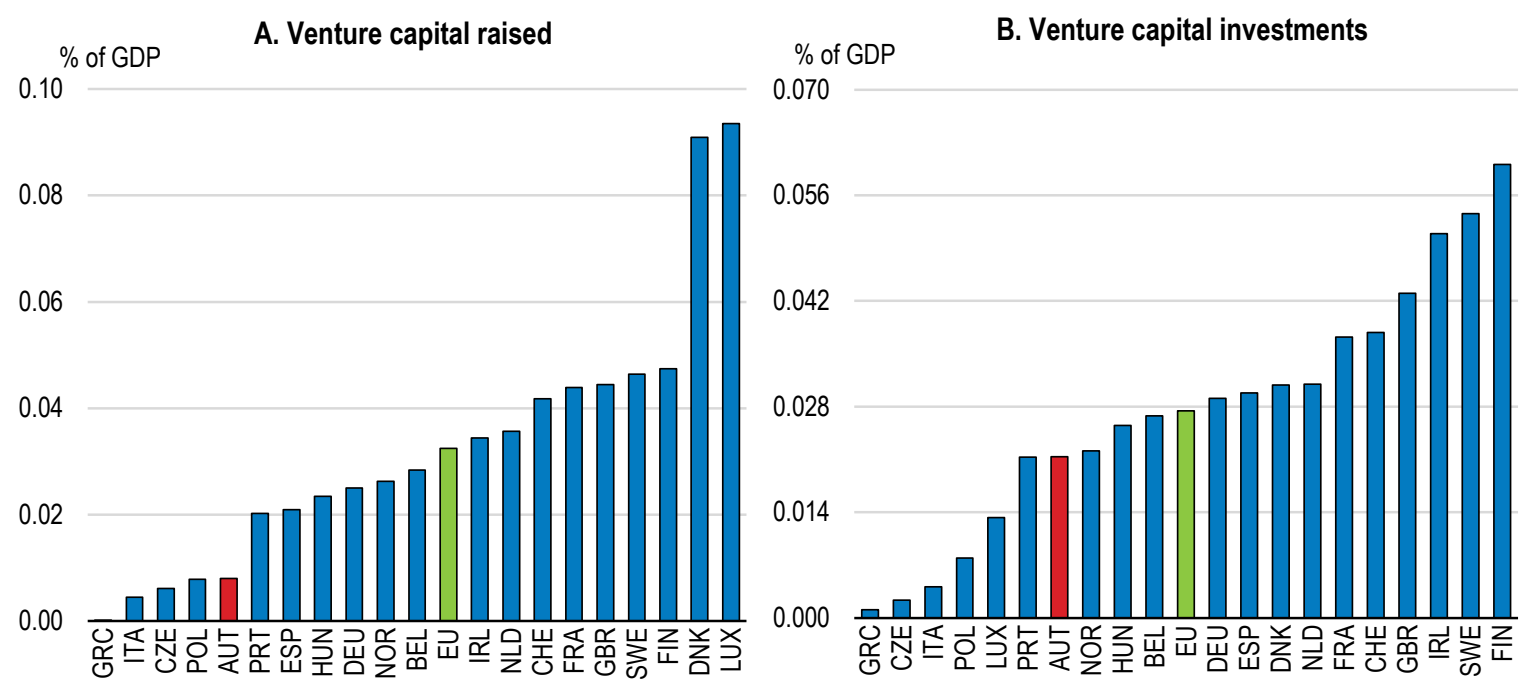

Note: Panel A records venture capital according to the location of the managing office and includes both domestic and foreign investments (industry statistics). Panel B records venture capital according to the location of the firms in the portfolio (market statistics) financed either by domestic or foreign venture capital funds.

Source: Invest Europe, European Private Equity Activity Data 2017 


\section{Figure 21. Growth capital markets are not well developed}

Growth capital raised and investments, average between 2013 and 2017

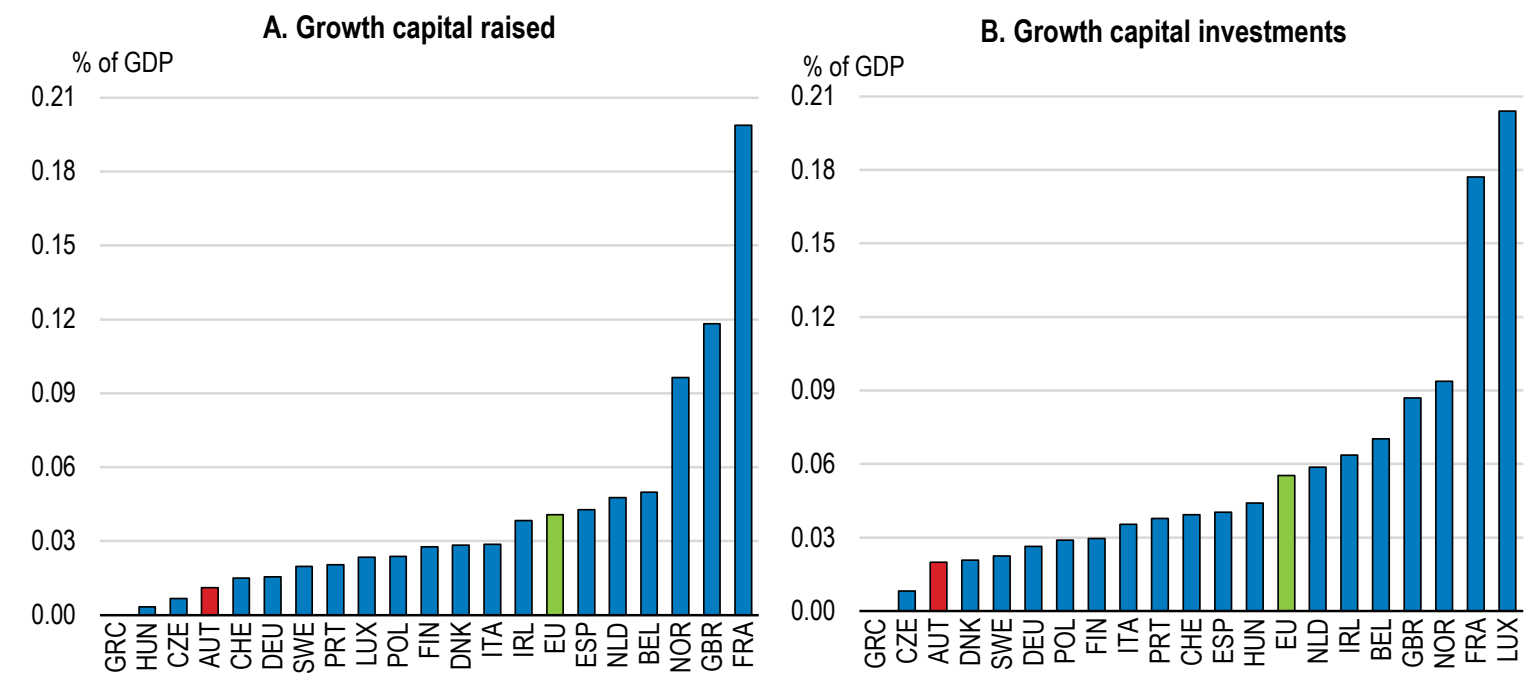

Note: Panel A records growth capital according to the location of the managing office and includes both domestic and foreign investments (industry statistics). Panel B records growth capital according to the location of the firms in the portfolio (market statistics) financed either by domestic or foreign growth capital funds.

Source: Invest Europe, European Private Equity Activity Data 2017

The lack of an equity eco-system and the resulting low numbers of Austrian venture capital investors not only limits financing, but also has implications on the human capital of entrepreneurs. The role of venture capital investors goes beyond the sole provision of risk capital. They provide companies in their portfolio with several services related to consulting, finance, accounting, marketing, strategic foresight and human resources, which entrepreneurs would otherwise need to acquire outside (Colombo and Grilli, 2010). Entrepreneurs may also benefit from accessing the network of the venture capital investors and obtain access to other resources and skills (Hsu, 2006; Bottazzi, Da Rin, and Hellmann, 2008). Given these positive local externalities, the need to better develop local venture capital markets thus do not vanish in light of initiatives at the European level aiming at improving European venture capital markets.

Austrian authorities addressed the relatively low start-up rates with the introduction of a new Start-Up Package, which was introduced in May 2019. The Start-Up package consists of a series of measures to boost Austria's attractiveness as a start-up location, notably the establishment of a new "Digitalization and Growth Fund", more credit guarantees, regulatory sandboxes and new educational programmes. Tax incentives to leverage long-term private engagement in new ventures were not part of this reform. The Mittelstandsfinanzierungsgesellschaftengesetz, a legislation enacted in 2017 , is intended to facilitate the access to equity capital for start-ups and young firms. The law constitutes a tax incentive for investments in special purpose vehicles (the "Mittelstandfinanzierungsgesellschaften") which provide risk capital to firms that fulfil pre-defined criteria.

\section{Firming-up the tax system for the knowledge economy}

Helping businesses to prepare for the knowledge economy is likely to require great reliance on equity capital to underpin the necessary investments in knowledge capital, in part because it is harder to collateralise for loans. Reforms of the tax systems can go a long way in levelling the playing field between debt and equity by reducing the bias towards the former. Corporate tax rates in Austria have been decreasing from $34 \%$ in 2005 to $25 \%$ today (Box 4). Nevertheless, the Austrian authorities aim at further 
reducing the corporate tax rate through tax reform in 2019 by reducing corporate income tax rates towards $21 \%$ in 2023 . A reduction in the corporate income tax rate would also help to reduce the tax bias towards debt. Another way to address the debt-bias would be an allowance for corporate equity, which would give Austrian enterprises, an incentive to employ more equity capital.

\section{Box 4. Corporate income taxes in Austria in a nutshell}

Statutory corporate income tax rates in Austria currently stand at $25 \%$ and are slightly higher than in the OECD average or peer countries (Figure 22). However, revenues from corporate income taxes in Austria are only slightly more than $2 \%$ of GDP. As a comparison, while the statutory corporate income tax rate for the average of OECD and peer countries is lower, their tax revenue from corporate taxes is higher. However, this comparison needs to be interpreted with some care, as revenues from corporate income tax rates may vary with the business cycle and also depend on other factors.

\section{Figure 22. Revenue and rates for corporate income tax}

Corporate income tax revenue and statutory corporate income tax rate ${ }^{1}$

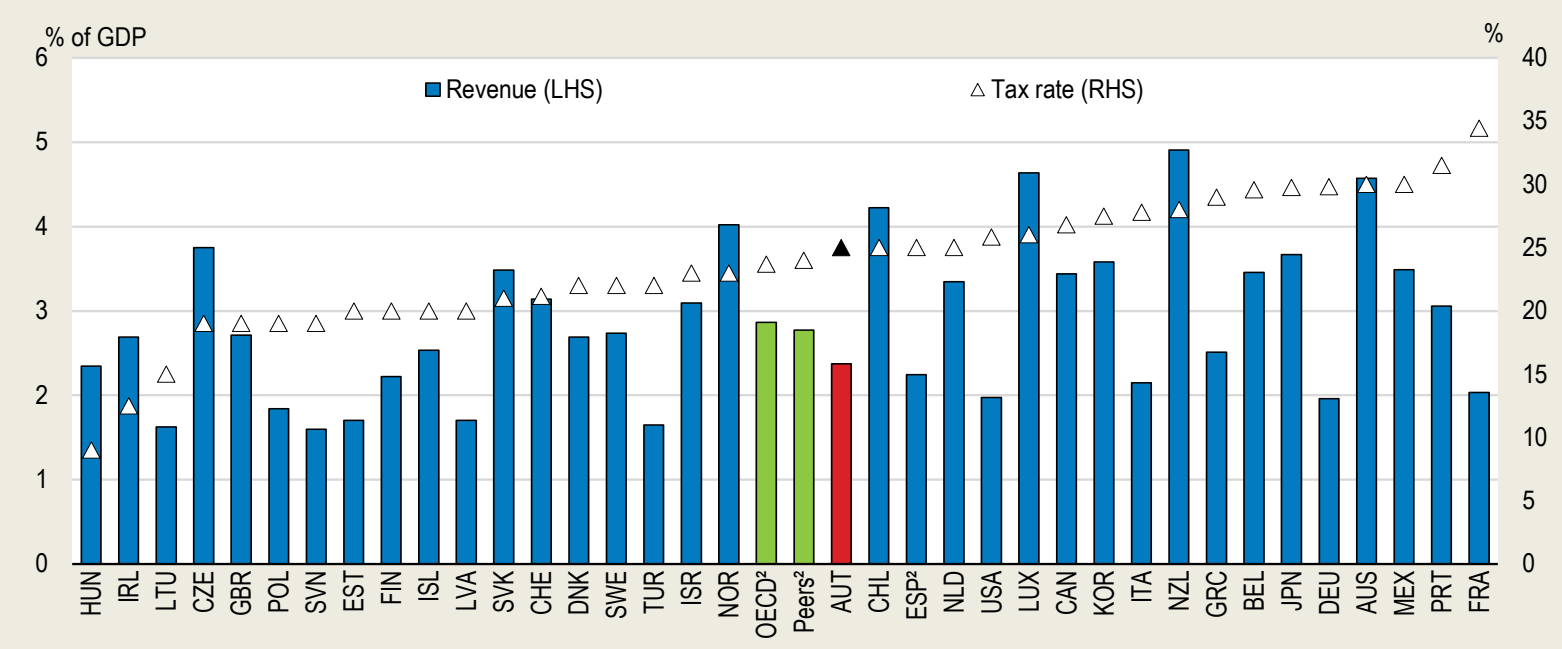

1. Data on tax revenue in 2016, but corporate income tax rate in 2018. Basic combined central government and sub-central government corporate income tax rate.

2. For Spain, the total tax revenue has been reduced by the amount of any capital transfer that represents uncollected taxes. Unweighted average for OECD and unweighted average of Denmark, Sweden, Germany, Switzerland and the Netherlands.

Source: OECD (2019), OECD Taxation Statistics (database).

Recent work by the OECD Centre for Tax Policy and Administration by Hanappi (2018) provides forwardlooking effective corporate income taxes for hypothetical investment projects, following a wellestablished methodology (e.g. Devereux and Griffith (1999); Devereux and Griffith (2003)). The framework disentangles effective average and marginal tax rates. Average corporate income tax rates measure the extensive margin of an investment project, i.e. the yes or no decision to start a specific investment project. Marginal effective tax rates measure the incentive to expand an investment project given that it has already started.

Effective average corporate income taxes in Austria are with around $24 \%$ slightly higher than the OECD average and in peer countries (Figure 23, Panel A). Effective marginal tax rates stand at roughly $14 \%$, nearly twice as high as in peer countries and above the OECD average of around $9 \%$. However, the OECD average without Italy and Belgium, two countries with large negative marginal effective tax rates, is with around $11 \%$ much closer to the marginal effective tax rate in Austria. 
The framework of Hanappi (2018) further allows to quantify effective tax rates for different investment goods. Whereas average effective tax rates for intangible investment in Austria are with $26 \%$ slightly above the OECD average and peer countries, effective marginal tax rates are more than four times higher in Austria than in peer countries (Figure 23, Panel B). Here, investment in intangibles is confined to the acquisition of intangibles outside the firm. It also excludes further investments to make it usable, e.g. investments in upskilling the staff to use a new technology.

Figure 23. Effective marginal corporate income tax rates are high particularly for intangible investment

Effective average and marginal corporate income tax rates ${ }^{1}, 2017$
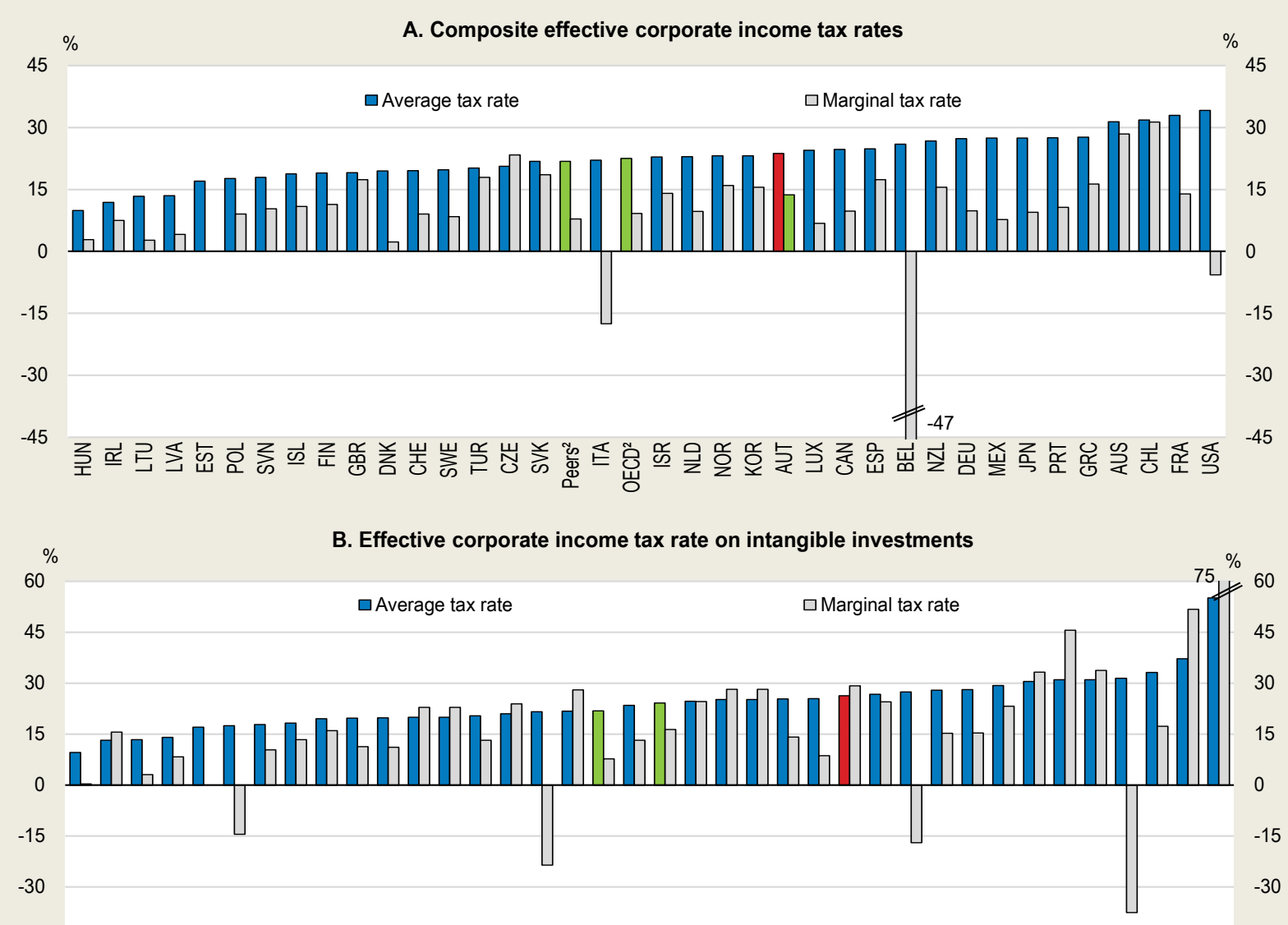

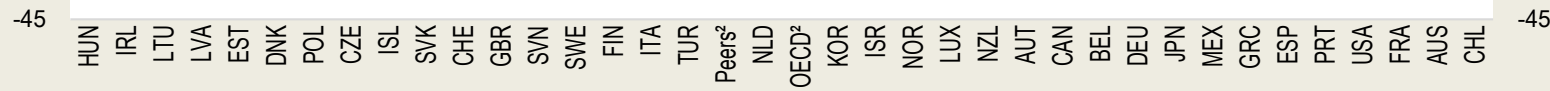

1. Based on the framework of Hanappi (2018) with a scenario assuming real interest rates of $3 \%$ and an inflation rate of $1 \%$ across all countries.

2. Unweighted average for OECD and unweighted average of Denmark, Sweden, Germany, Switzerland and the Netherlands.

Source: OECD (2019), OECD Taxation Statistics (database) and T., Hanappi (2018), "Corporate Effective Tax Rates: Model Description and Results from 36 OECD and Non-OECD Countries", OECD Taxation Working Papers, No. 38.

Most corporate tax systems treat debt financing and equity financing differently (ZEW, 2016). In many countries including Austria, the interest expenses on existing debt, can be deducted from pre-tax earnings, thereby lowering taxable income, leading to a lower tax liability. Usually, the returns on equity capital cannot be deducted. Thus, an investment project solely financed through debt generates a higher post-tax return 
on investment than the same investment project financed through equity. This leads to different effective corporate income tax rates for different sources of financing (ZEW, 2016). However, the debt-bias pertains only to the corporate income tax system. At the personal income tax level interest income is typically taxed while dividends may benefit from exemptions and credits.

The debt bias incentivizes entrepreneurs, from a tax point of view, to finance new investments with debt instead of equity. The rise of the knowledge-based economy, requires significant investments in intangible capital and experimentation with new technologies, business models and ideas, and may require financing through equity. Thus, the debt bias of corporate tax systems tends to be a limiting factor. Further, the debt bias appears to be large (ZEW, 2016). The difference between the effective average tax rates on investment projects entirely financed through debt and projects entirely financed through newly issued equity is around 9\% in Austria, which is above the EU28 average of 7.6\% (ZEW, 2016).

One way to address the debt bias of the corporate tax system is to grant an allowance for corporate equity. While such an allowance is appealing from a theoretic point of view, there are challenges related to its successful implementation and it may have negative side-effects. As a result, very few countries currently have such a measure in their corporate tax regime. Since 2006, Belgium has an allowance for corporate equity (Zangari, 2014). Italy had a similar scheme from 2011 to 2019. Austria experimented with a tax reform similar to a corporate allowance for equity in the period between 2000 and 2004 (Genser, 2002). Here, Austria granted a reduced corporate tax rate of $25 \%$ (instead of the statutory $34 \%$ corporate income tax rate at that time) on the notional return on equity. However, after a cut to corporate taxes to $25 \%$, this reduction became obsolete (De Mooij and Devereux, 2009).

The evidence on economic impacts of the allowance for corporate equity from the few existing examples so far supports the conclusion that the allowance for corporate equity reduces leverages ratios of firms. For Belgium, the deduction appears to have decreased the degree of financial leverage significantly (Princen (2012), Panier et al. (2013)), though Campenhout and Caneghem (2013) find no impact on SME's leverage. Branzoli and Caiumi (2018) provide empirical evidence that the allowance has reduced leverage ratios in Italy, though more for older firms and smaller firms. Empirical results for Austria point in the same direction, as the tax reform in 2000 was associated with reduced long-term liabilities (Frühwirth and Kobialka, 2011).

The Belgian case suggests that the reduction in leverage coincided with increased intra-group lending within multinationals with no effects on investment (Hebous and Ruf, 2017). The implementation of an allowance for corporate equity requires a careful design to avoid any incentive to cross-border tax planning. In particular, a key challenge of such an allowance pertains to the identification of the book value of equity and its evolution over time. Further, the allowance may have substantial budgetary costs if applied to existing capital only (Zangari, 2014). In the case of Belgium, the allowance reduced the corporate tax yield by around $10 \%$ in 2008 . Italy was able to limit tax planning of multinationals through an effective antiavoidance framework and avoided pressure on budgetary costs by applying the allowance on newly issued equity capital only (Zangari, 2014).

\section{Addressing skill shortages to unleash the full potential of Austrian SMEs}

As discussed in detail in the Key Policy Insights chapter, ensuring an effective match of skills for Austrian firms will play an important role in achieving the digital transformation and in their future success in world markets. Technological progress and digitalization allow for greater scope for automation, putting some jobs at risk while also creating new types of jobs. Increased adoption of ICT technologies and new technological discoveries put pressure on countries to develop skills in computer sciences, electronics, mathematics, physics and engineering. Although the transition towards a digital economy has been underway for nearly half a century, the pace recently became quicker (OECD, 2017) and employment in Austria has been heavily affected by technological progress and the digital transition (Figure 24). 
Actively addressing the increased skill shortages through reforms across all education layers from early childhood to life-long education, as was intended in the government programme 2017-2022 and discussed in the previous chapter become therefore crucial for preserving the dynamism, the international competitiveness and the future performance of Austrian SMEs throughout the territory. Two aspects of the broad education reform agenda are particularly important for SMEs: upgrading digital skills and activating the skills of migrants.

\section{Figure 24. Employment in Austria lost middle-skilled jobs but gained high-skilled jobs}

Percentage point change in the share in total employment between 1995 and 2015

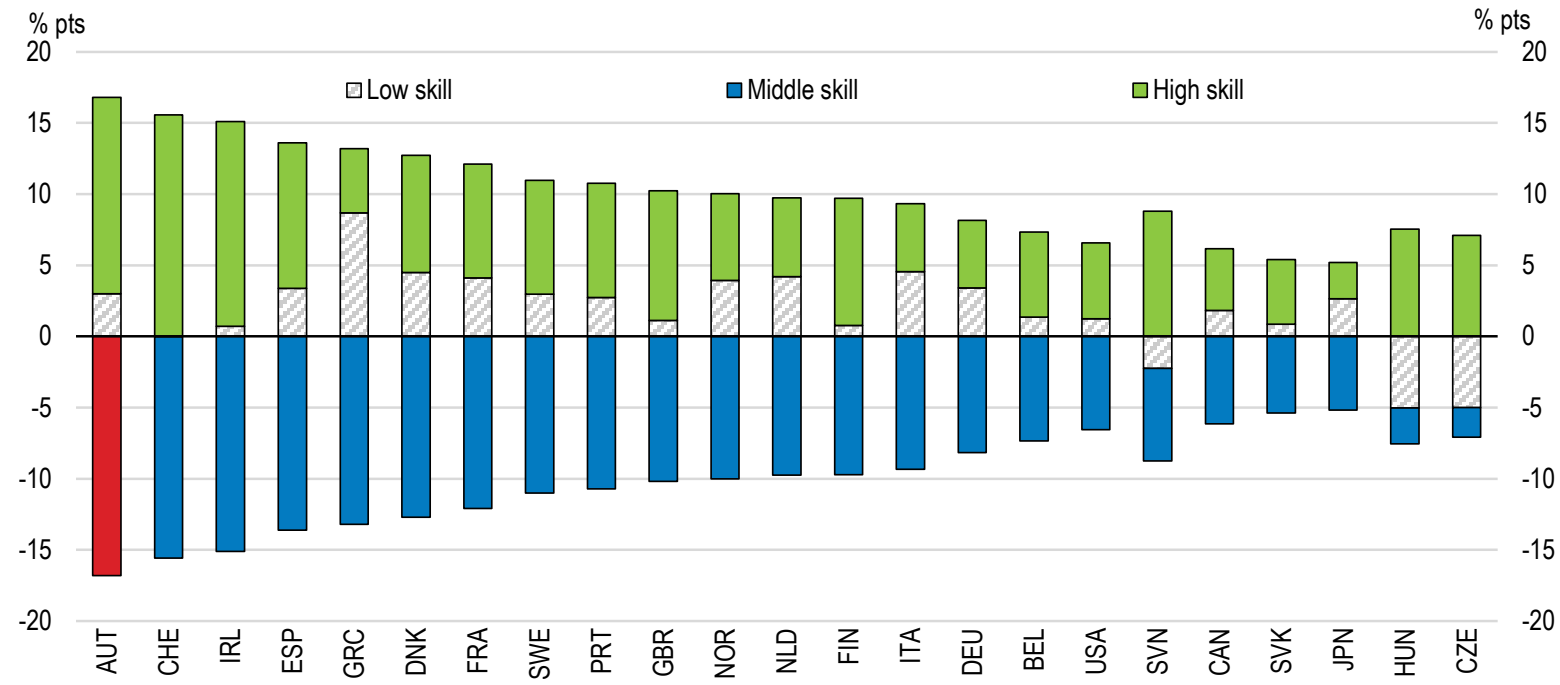

Note: High-skilled occupations include jobs classified under the ISCO-88 major groups 1, 2, and 3. These are legislators, senior officials, and managers (group 1), professionals (group 2), and technicians and associate professionals (group 3). Middle-skilled occupations include jobs classified under the ISCO-88 major groups 4, 7, and 8. These are clerks (group 4), craft and related trades workers (group 7), and plant and machine operators and assemblers (group 8). Low-skilled occupations include jobs classified under the ISCO-88 major groups 5 and 9 . These are service workers, shop and market sales workers (group 5), and elementary occupations (group 9).

Source: OECD (2017), OECD Employment Outlook 2017.

\section{Upgrading digital skills}

Austria is among the countries where shortages of computer and electronic skills and mathematical skills are critical (see KPI). Further, according to the OECD Survey of Adult Skills (OECD, 2013), Austrians of all ages show only average proficiency with ICT skills, both at home and work. The lack of knowledge and skills related to ICT technologies constitute a major impediment to the adoption of these technologies and productivity growth. Simulations based on the empirical framework of Gal et al. (2018) illustrate, that improving skills related to the use of ICT technologies and management to the best-performing OECD country could boost productivity performance of the average Austrian firm by about $3 \%$ within a 3 year period. Managerial skills have direct and indirect effects on productivity performance through digital adoption. On the hand, good management tends to increase the probability of ICT adoption (Andrews et al., 2018). On the other hand, low levels of management skills are associated with lower productivity gains from employing ICT technologies (Gal et al., 2018). The beneficial effects on productivity from better ICT skills are larger than from other structural policies and underline the severity of the skill constraint in adaption to a knowledge economy. Recognising the need for skills related to ICT technologies in Austria, many institutes of higher education and in particular Universities of Applied Sciences involve business stakeholders in the design of the curricula (OECD, 2019c). This allows graduates from Universities of Applied Sciences to acquire skill profiles that are in line with the requirements of the regional labour market. 
Furthermore, also public universities have progressed in this direction by cooperating with the Chamber of Commerce and other government agencies such as regional development agencies (OECD, 2019c) The authorities are introducing additional measures to improve digital skills including the "Digital Competence Pact", which aims at building basic digital skills and the "fit4internet" program, targeted towards seniors and more experienced professionals. Given the widespread apprenticeship system in Austria, authorities also need to ensure that apprenticeship programs incorporate future needs for digital skills. In this respect, the initiative of the Federal Ministry for Digital and Economic Affairs in Summer 2018 to create the two new programs in "Coding" and "IT technology" and the modernisation of existing programs to better incorporate digital skills is welcomed.

\section{Activating the skills of migrants}

A potential pool of untapped talent, which is available today and can help to address the skill shortages of SMEs are high-skilled migrants. The difficulty of mobilising the skills of migrants can be partly explained by the lengthy and cumbersome recognition process of foreign diplomas. According to a survey conducted by Statistik Austria, 3 out of 4 non-EU workers received their qualifications outside, but only $25 \%$ apply for recognition (Statistik Austria, 2015). A new comprehensive legal Recognition Act was introduced in 2015, which helped to facilitate the transparency and efficiency of the recognition of non-EU qualifications. However, Austria is one of only few OECD countries which do not grant a legal right to have prior learning recognised. Yet some immigrants may have skills and knowledge resulting from profound work experience or other forms of learning without a formal diploma (OECD, 2017f). Moreover, the recognition of prior learning can serve as a way to identify additional training needs (OECD, 2017f) and help immigrants to address the specific skill gap. Austria can also improve on bridging programmes, which aim at improving existing, however, not yet sufficient, skills to the domestic standard. Although, bridging programmes in Austria exist, they tend not to be systematic and do not tackle all regulations (OECD, 2017f).

Austria's has a high level of international student intake, which represents a further significant, but untapped, potential to attract more high-skilled workers. International students, who cross borders for the specific purpose of studying, account for $16 \%$ of all enrolments in Austria - a share almost three times bigger as the OECD average (Figure 25, Panel A). Yet, only $17 \%$ of international students stay after finishing their studies in Austria, the lowest share of countries with available data (OECD, 2014). Further, the higher their final degree, the less international students stay in Austria (Figure 25, Panel B). For graduates from non-European countries, policymakers can address this discrepancy by facilitating the process of obtaining an employment permit. In Austria, non-EU citizens can apply for the Red-White-Red card, a combination of residence permit and employment permit, valid for two years and bundled to a specific employer. The Red-White-Red card is mainly targeted at skilled workers and shortage occupations. Graduates from non-EU countries can apply for the Red-White-Red card in a facilitated procedure. This procedure is intended to be modernized by lowering the statutory salary threshold and by eliminating the proof of accommodation needed. In particular, applicants can obtain the Red-White-Red card if they find a job, which matches their educational level, within 1 year after graduation. Austrian authorities need to analyse whether this fast-track application for graduates from non-EU countries is sufficiently attractive to retain international talent. Besides high skilled workers already residing in Austria, authorities should also optimize the search for qualified workers from abroad. In this respect, the initiative of the government to transform the national investment promotion agency ABA into a locational agency also specializing in attracting foreign high skilled workers should be pursued further. Success with these policies would help alleviate the skill shortages of many SMEs throughout the territory. 
Figure 25. Austria attracts many international students but few stay after graduation

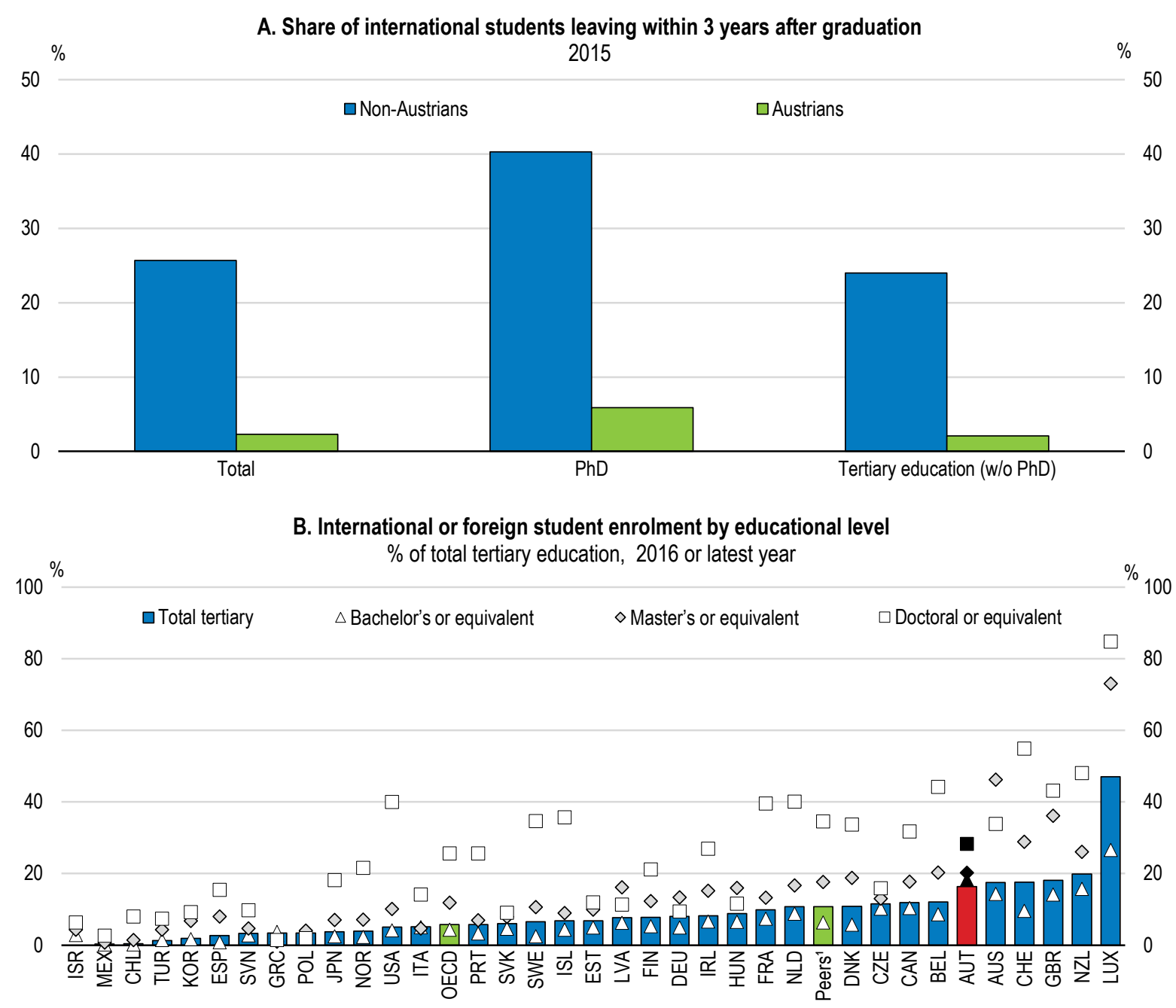

1. Unweighted average of Denmark, Germany, the Netherlands, Switzerland and Sweden.

Source: OECD (2018), OECD Education at a Glance 2018: OECD Indicators and Statistik Austria, Statistisches Jahrbuch "migration \& integration". Zahlen.daten.indikatoren

\section{Business transfers can accelerate SMEs' growth}

\section{Ageing will increase the number of business transfers}

Business transfers represents a critical stage in the life of a company and many Austrian firms are now reaching this point. On the one hand, business transfer constitutes an opportunity to rethink the strategy of the business, improve business processes and update the state of technology. Furthermore, business transfers provide an opportunity to take up entrepreneurship, in particular for otherwise disadvantaged groups, like women or high-skilled migrants. On the other hand, many economically vibrant businesses exit the market due a result of problematic business transfers, thereby putting employment, innovation and social inclusion at risk (OECD, 2018f). For example, in the European Union, around 450000 SMEs change ownership annually, affecting more than 2 million employees, but up to one-third of these transfers may not be successful, thus putting around 150000 enterprises and 600000 jobs at risk (European Commission, 2013). 
The evidence base on business transfers and succession is generally scarce and mostly relies on employer surveys. Sufficient information on business transfers, especially for different firm typologies, sectors and entrepreneur's characteristics is missing. However, this information would be useful to identify success factors in business transfers and how structural policies can shape these factors. According to a survey conducted by the Federal Ministry of Science, Research and Economy and the Federal Economic Chamber, 45700 SMEs will be handed over in the period 2014-2023, around one-third of all businesses (KMU Forschung Austria, 2014). There are regional disparities in the absolute numbers, as lower Austria will need to manage 7800 business transfers but Vorarlberg only 2400 (KMU Forschung Austria, 2014). The potential economic effects are large. Between 200000 and 450000 employees are likely to be affected, which constitutes a share of 5-10\% of total employment (Table 3). The need for business transfers varies across sectors. The majority of business transfers in the 2017 period were in trade and commerce sectors, the tourism sector and ICT services (KMU Forschung Austria, 2014).

\section{Table 3. Employment and turnover affected through potential business transfers in SMEs}

Business economy, 2014-2023

\begin{tabular}{l|c|c|c}
\hline & Affected employment (persons) & $\begin{array}{c}\text { Affected average employment } \\
\text { (persons) }\end{array}$ & Real turnover (Billions, EUR) \\
\hline Burgenland & 8000 & 15000 & 20 \\
\hline Carinthia & 17000 & 32000 & 40 \\
\hline Lower Austria & 39000 & 77000 & 100 \\
\hline Upper Austria & 35000 & 68000 & 50 \\
\hline Salzburg & 20000 & 39000 & 70 \\
\hline Styria & 29000 & 57000 & 65 \\
\hline Tyrol & 26000 & 1000 & 30 \\
\hline Vorarlberg & 12000 & 24000 & 115 \\
\hline Vienna & 45000 & 88000 & 580 \\
\hline Austria & 231000 & 451000 & 30 \\
\hline
\end{tabular}

Note: SMEs exclude firms with one person. Projection of turnover under the assumption of constant turnover growth.

Source: KMU Forschung Austria.

The high share of family owner enterprises further exacerbates the business transfer problem. Around half of all Austrian enterprises (excluding one person enterprises) are family-owned enterprises. According to EU definitions, to qualify as a family enterprise, at least one member of the family participates in the management of the company and the founding family holds the controlling rights over the company. The majority of jobs and total turnover in Austria in 2015 were provided by family enterprises (WKO, 2018). A business transfer within a family raises additional problems. Business transfer within a family need to take care of more factors than outside the family (Zehrer, 2016). First, an owner with more than one child needs to pick a potential transferee while ensuring family cohesion and sufficient provision for the other children. Second, family ties between the former and new owner likely raise problems if the former owner still tries to manage the company and is reluctant to let go (Zehrer, 2017).

The link between the involvement of family members in management in family owned enterprises and managerial quality can be beneficial but also raise some challenges. On the one hand, family involvement can go a long way in mitigating conflicts between principal and agents. Since family firms are highly exposed to their own firms in terms of ownership and much less or not at all to other firms through portfolio holdings, they profit to a greater extent from good managerial decisions but are also more affected by bad corporate decisions (Cheng, 2014). Family firms also help to address managerial myopia, as family firms tend to have longer investment horizons compared to other shareholders (Pahnke and Weber, 2018). On the other hand, empirical evidence from firm surveys shows that management of family firms that follow 
succession rules based on primogeniture has significantly lower quality (Bloom and Van Reenen, 2010). The same survey further suggests that the negative effect of family internal succession on managerial quality is less severe if the set of potential successors within the family is broader, i.e. does not only include the eldest son (Bloom and Van Reenen, 2010). No significant deterioration of managerial quality is found if a family owned firm appoints a manager from outside the family (Bloom and van Reenen, 2007). However, these results may be partly explained by a different perception of responsibilities of CEOs of family-owned enterprises and a less strong emphasis on maximisation of shareholder value. Indeed, Mullins and Schoar (2016) provide survey evidence that founders and CEOs of firms with greater family involvement tend to have a greater focus on stakeholders, in particular towards their own employees and banks.

A significant number of Austrian businesses are organised under the umbrella of a foundation. According to estimates to the Federation of Austrian Foundations, around $10 \%$ of total employment in Austria is working in a foundation owned company. Initially in 1993, authorities enacted a law, the "Stiftungsgesetz", to foster the creation of foundations and granted significant tax advantages to foundations. The underlying idea was to counteract outflows of capital and subsequent losses in employment. The law was supposed to keep family-owned enterprises within the family and thus avoided the need to split up firms in case successors could not agree on the continuation of the firm. After various changes to the "Stiftungsgesetz", the governance of foundations appears to be too restrictive. Beneficiaries of the foundation or close family members of beneficiaries are excluded from the management of the foundations, thereby they have no control over the management of the company. This implies that the foundation can block business decisions of the management of the company if not foreseen in the initial will of the owner of the company who created the foundation. Austrian authorities should therefore take a careful look at whether the current "Stiftungsgesetz" constitutes an impediment to successful business transfers, for example by blocking transfers within and outside the family even if the current generation of beneficiaries would be in favour of it. One way to improve the governance of foundations could be to grant more controlling rights for the beneficiaries in supervisory boards, either by allowing their voting share to be greater than two thirds or by increasing their power in appointing and removing members of the board of the foundation.

\section{Increasing the number of potential transferees}

Austrians appear to have a strong entrepreneurial spirit. The share of the working-age population who considers themselves capable of start a business is among the highest across the OECD (Figure 26). Fewer Austrians than the OECD average express fear of failure as reason preventing them from setting up a business (Figure 27). In general, Austria performs well in indicators regarding early stage entrepreneurial activity, but only few Austrians considering entrepreneurship as a desirable career choice, which may reflect framework conditions for entrepreneurship and a preference for the numerous lower-risk job opportunities in existing firms (European Commission, 2018). Although, survey results based on selfevaluation need to be taken with care, total early-stage entrepreneurial activities of Austrians were above the EU average (OECD, 2017d) and thus confirm the entrepreneurial spirit of Austrians. 
Figure 26. Austrians perceive themselves as capable for entrepreneurial activity...

Percentage of 18-64 year-old population, who believes they have the required skills and knowledge to start a business

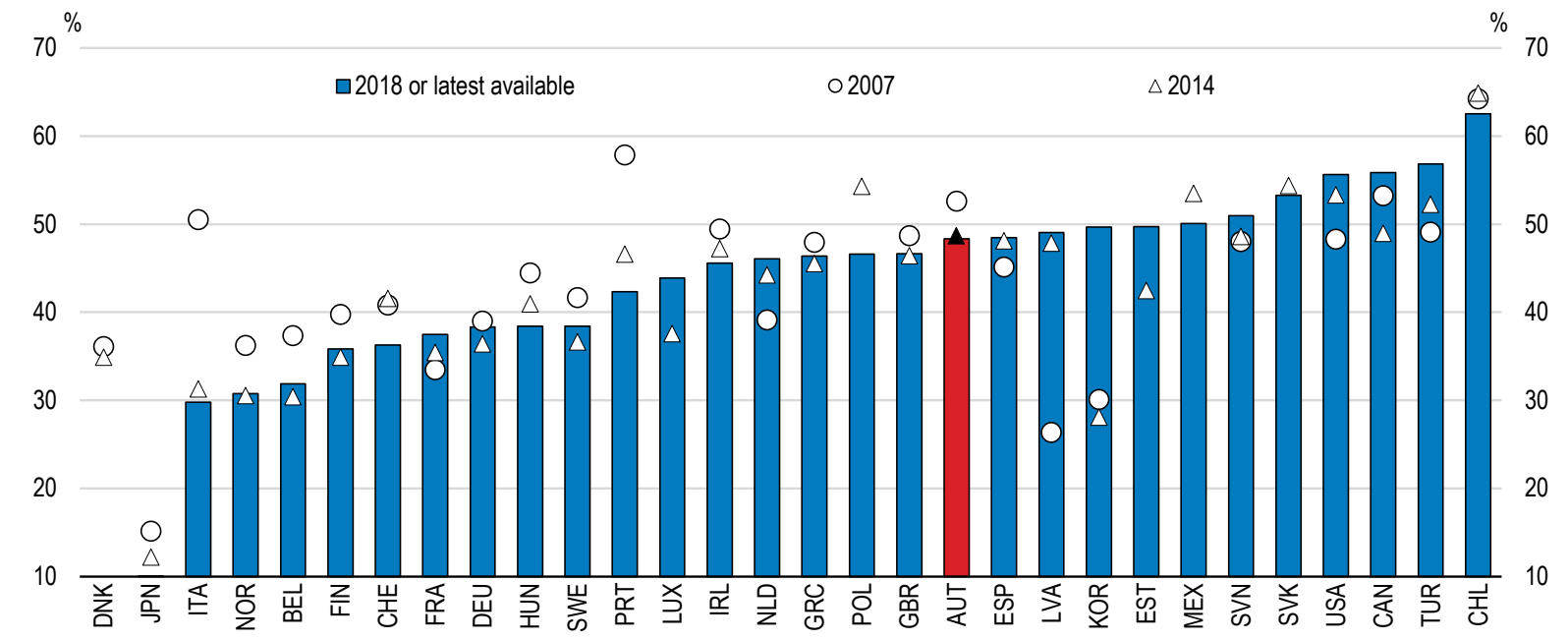

Note: Canada, Germany in 2006 for 2007 and Korea in 2008 for 2007. Korea, Latvia and Turkey in 2013 for 2014.

Source: Global Entrepreneurship Monitor (2019), Entrepreneurial Behaviour and Attitudes (database), www.gemconsortium.org/data/key-aps.

Figure 27. ... and have less fear of failing than elsewhere

Percentage of 18-64 year-old population, who indicates that fear of failure would prevent them from setting up a business

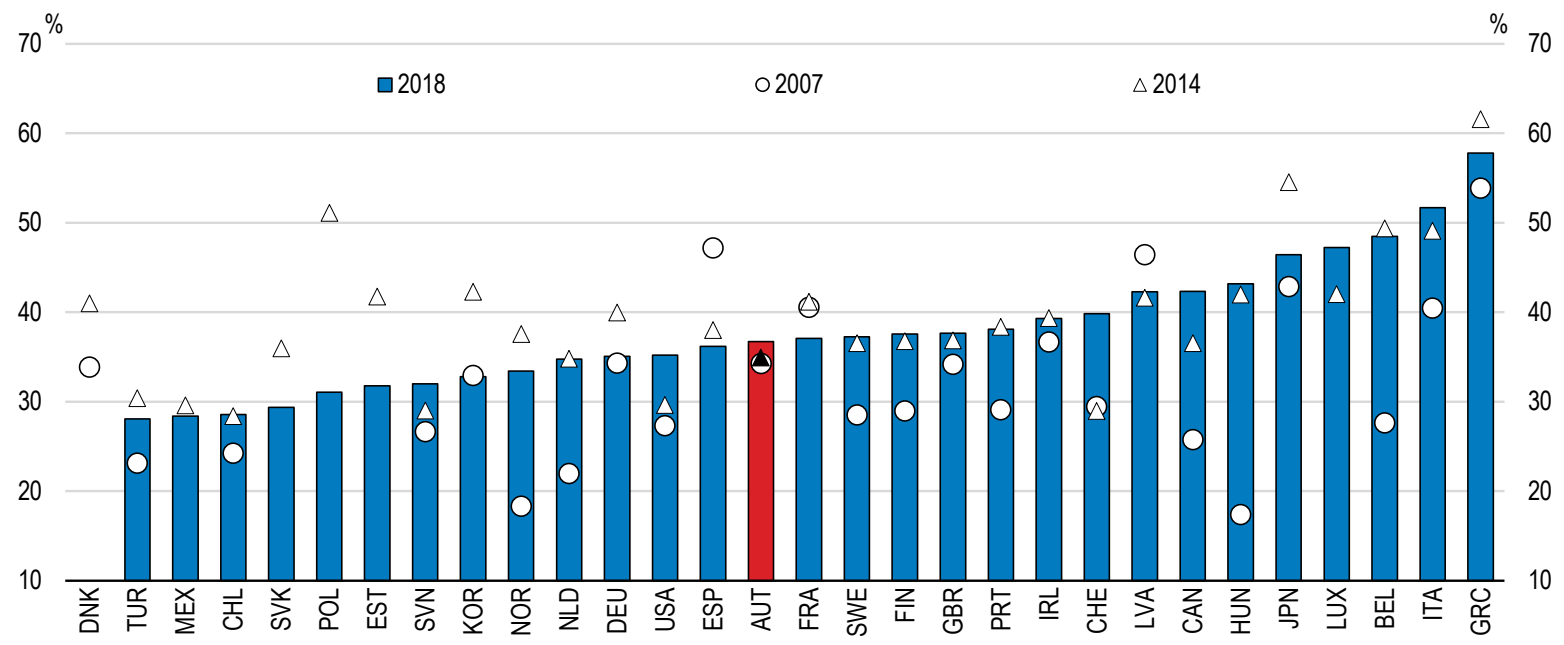

Note: Canada, Germany in 2006 for 2007 and Korea in 2008 for 2007. Korea, Latvia and Turkey in 2013 for 2014.

Source: Global Entrepreneurship Monitor (2019), Entrepreneurial Behaviour and Attitudes (database), www.gemconsortium.org/data/key-aps.

Austrian women still constitute a large untapped pool of resources available for as potential transferees. Although the uptake of early-stage entrepreneurial activity of Austrian women is above the EU average (OECD, 2017d; European Commission, 2018), fewer women in Austria than elsewhere are actually selfemployed with employees (OECD, 2018g). This points towards a general high interest in entrepreneurship among women in Austria, but also suggests that fewer women than elsewhere scale-up their business. 
Authorities need to ensure the right framework conditions for women to work as entrepreneurs. This includes sufficient child-care facilities across the country, eliminating any tax incentives for women to stay home and encouraging men to take up their part of care responsibilities over children and elderly.

Failed business transfers entail huge economic risks, for example job losses, negative spill-over effects on local suppliers and a loss of human and organisational capital. Further, pending transfers may already lead to adverse economic effects. Pending transfers may induce customers or suppliers to refrain from business deals, due to uncertainty over the firm capacity to guarantee supply in the long-term. Failed transfers also negatively affect the individual entrepreneur and their families including family wealth. Potential transferees from outside Austria and the European Union are already able to apply for the so-called Red-White-Red Card, a special form of work visa for skills needed in the Austrian economy, as self-employed key workers. In order to improve the framework conditions and facilitate business transfers, planned measures by the former government, such as the simplification of administrative procedures, the abolishment of obstacles that might occur from trade regulations and even tax reliefs should be considered.

\section{Ensuring a supportive tax systems and sufficient financing}

Austria abolished inheritance taxes in 2008. However, as discussed in greater detail in the KPI, inheritance taxes are an effective way to tackle wealth inequality, which has risen over the last decade (OECD, 2018g). Therefore, in light of the planned reform of tax systems in 2019, Austrian authorities could consider reintroducing an inheritance tax. Tax relief could be provided for business assets to avoid family-owned businesses having to be split up when the property is transferred (because recipients are forced to sell parts or all of the business to pay the tax). However, such tax relief would have to be well-targeted to prevent tax planning and abuse. In particular, the tax relief should focus on productive business assets, ensure the continuation of the business and avoid that the heirs can immediately sell business assets after the donor's death without having to pay inheritance taxes.

Business transfers entail complex tax consequences. A transfer within the family raises different tax considerations as compared to an external transfer. Internal transfers often are a mixture of gift and money exchanges, which are not taxed by income taxes. However, the new owner faces capital gains taxes assessed on the difference between market and book value. The different tax consequences aggravate the complexity of business transfers and thus may require substantive long-term planning. Here, there needs to be adequate provision of consulting services available for potential transferees. These consulting services should not only include advice on legal and tax matters, but also on communication and ahead planning of business transfers (Zehrer, 2016). Further, services related to accounting, due diligence and valuation are needed in order to ensure timely and efficient transfers.

The takeover of established businesses often requires an injection of new financial capital. Whereas $83 \%$ of all business transfers within the family did not involve any new fund raising, only $9 \%$ of all business transfers outside the family did so (WKO, 2014). The financing possibilities include mergers and acquisitions, initial public offerings, transfer of ownership to foundations, employee buy-outs or management buy-outs and buy-ins. Smaller businesses typically rely on personal resources from the owner when a transfer or selling takes place. An additional financial weakening can occur when other family members need to be paid out (OECD, 2017). The previous government considered scaling up the existing aws Pre-/Seed programme to provide start-ups with financing, but also with assistance and educative measures. However, these programmes should include business transfers as well and provide equity capital to transferees. In order to ensure the long-run success, the provision should be conditional on the transferee to continue to hold the business for a sufficient amount of time.

\section{Increasing awareness for the importance of business transfers}

A general awareness campaign to inform SME owners about the importance of succession planning, and potential entrepreneurs about the opportunities emerging of business transfers would help to facilitate SME 
business transfers. In this respect, the Overdrachtspakket, launched as a large-scale campaign by the Dutch Ministry of Economic Affairs serves as an example of best practice. The Overdrachtspakket consists of series of brochures on legal, financial and other important aspects that need to be considered and is distributed to every entrepreneur above the age of 55. Authorities have already started initiatives to increase awareness for business transfers, including the "Nachfolgebörse" (succession bourse) of the Federal Economic Chamber, which helps to connect potential transferees and business owners.

\section{Key recommendations}

\section{Firming up the capital structure of the Austrian business sector}

- Further identify and address the remaining shortages in the ecosystem for equity investments in forms of all sizes. Further draw on the completion of EU capital market union.

- As intended in the tax reform strategy of the previous government, modify corporate taxes to reduce disincentive effects and the debt-bias.

\section{Addressing skill shortages to unleash the full potential of Austrian SMEs}

- Continue to attract high-skilled foreign workers and retain more foreign graduates of Austrian universities by facilitating their access to red-white-red cards.

\section{Business transfers as an engine for SME growth}

- Take up the measure planned by the previous government to facilitate business transfers.

- Improve the evidence base on business transfers and identify factors contributing to successful business transfers by developing a publicly available firm-level database of SMEs' annual reports and information on owners.

\section{Other recommendations}

\section{Firming up the capital structure of the Austrian business sector}

- Improve the provision of equity capital by using financial literacy as a tool to boost stock market participation and financial knowledge of entrepreneurs, while ensuring that financial literacy is gender- and age-inclusive.

- Review the protection of minority shareholders and improve rules on preventing self-dealing to international standards.

\section{Addressing skill shortages to unleash the full potential of Austrian SMEs}

- Grant a legal right to have prior learning of immigrants recognised.

\section{Business transfers as an engine for SME growth}

- Facilitate business transfers by reducing regulatory and legal burdens related to transmissions.

- Ensure support for business transfers related to planning ahead and legal and financial advice, in particular targeted to small- and medium-sized family firms: Launch an awareness campaign to inform SME owners about the importance of succession planning and help disseminating best practices.

Increasing awareness of business transfers also includes improving the evidence base on business transfers. With the ultimate goal of identifying success factors in business transfer to better target policy measures, the underlying database should include data on personal characteristics of the owner merged 


\section{4 | ECO/WKP(2020)3}

with firm-level information for a sufficiently long period before and after a business transfer. Importantly, the database should also include information on failed business transfer in order to circumvent statistical problems related to the so-called "survivorship-bias". Furthermore, the firm-level information needs to contain data on economic outcomes, like employment, investment in tangibles and intangibles, but also financial variables, like internal and external financing sources. In this respect, the annual "SME report" of the Federal Ministry for Digital and Economic Affairs with data on projected number of successions and the dedicated study on business transfers, which is jointly published every five years with the Federal Economic chamber, constitute first steps in this direction. 


\section{References}

Adalet McGowan, M., D. Andrews, and V. Millot (2017), "Insolvency Regimes, Zombie Firms and Capital Reallocation", OECD Economics Department Working Papers, No. 1399.

Adalet McGowan, M., D. Andrews and V. Millot (2017),"The Walking Dead? Zombie Firms and Productivity Performance in OECD Countries", OECD Economics Department Working Papers, No. 1372.

AFME Finance for Europe (2017), "The shortage of risk capital for Europe's high growth businesses", Association for Financial Markets in Europe, London.

Aivazian, V.A., Y. Ge, and J. Qu (2005), "The impact of leverage on firm investment: Canadian evidence", Journal of Corporate Finance, Vol. 11(1-2).

Andrews, D., G. Nicoletti, and C. Timiliotis (2018), "Digital technology diffusion: A matter of capabilities, incentives or both", OECD Economics Department Working Papers, No. 1476.

Bai, J.J., D. Carvalho, and G.M. Phillips (2017), "The Impact of Credit on Labor Reallocation and Aggregate Industry Productivity”, NBER Working Papers, No. 24081.

Barberis, N. and R. Thaler (2003):"A survey of behavioural finance", in: Handbook of the Economics of Finance, Vol. 1 Part B.

Behrmann, J.R., Mitchell, O.S., Soo, C.K. and D. Bravo (2012):"How Financial Literacy Affects Household Wealth Accumulation", American Economic Review: Papers \& Proceedings, Vol. 102(3).

Belka, M., E. Nowotny, P. Samecki, and D. Ritzberger-Grünwald (2016): "Boosting European Competitiveness - The Role of CESEE Countries", Edward Elgar Publishing.

Bloom, N., and J. van Reenen (2007), "Measuring and Explaining Management Practices across Firms and Countries", The Quarterly Journal of Economics, Vol. 122 (4).

Bloom, N. and J. van Reenen (2010), "Why Do Management Practices Differ across Firms and Countries", Journal of Economic Perspectives, Vol. 24(1).

Bock, C., and M. Watzinger (2017), "The Capital Gains Tax: A Curse but Also a Blessing for Venture Capital Investment", Journal of Small Business Management, Vol. 0(0).

Bond, S., J.A. Elston, J. Mairesse, and B. Mulkay (2003),"Financial Factors and Investment in Belgium, France, Germany and the United Kingdom: A Comparison Using Company Panel Data", Review of Economics and Statistics, Vol. 85(1).

Boschman, K., and L. Pissareva (2017), "Fostering Markets for SME Finance", OECD SME and Entrepreneurship Papers, No. 6.

Bottazzi, L., M. Da Rin, and T. Hellmann (2008), "Who are the active investors?: Evidence from venture capital", Journal of Financial Economics, Vol. 89(3).

Branzoli, N. and A. Caiumi (2018),"How effective is an incremental ACE in addressing the debt bias? Evidence from corporate tax returns", European Commission Taxation Papers, No. 72 - 2018.

Brown, J. R., S.M. Fazzari, and B.C. Petersen (2009),"Financing Innovation and Growth: Cahs Flow, External Equity and the 1990s R\&D Boom", Journal of Finance, Vol. 64(1).

Brown, J.R., G. Martinsson and B.C. Petersen (2012), "Do financing constraints matter for R\&D", European Economic Review, Vol. 56(8).

Buca, A. and P. Vermeulen (2017), "Corporate investment and bank-dependent borrowers during the recent financial crisis", Journal of Banking \& Finance, Vol. 78.

Campenhout, G., T. V. Caneghem (2013),"How did the notional interest deduction affect Belgian SME's capital structure?", Small business economics, Vol. 40(2).

Cheng, Q. (2014), “Family firm research - A review”, China Journal of Accounting Research, Vol. 7. 
Cupak, A., Fessler, P., Silgoner, M.A., and E. Ulbrich (2018), "Financial literacy in Austria: a survey of recent research results", Monetary Policy \& the Economy Q1/18, Österreichische Nationalbank.

Colombo, M.G., and L. Grilli (2010), "On growth drivers of high-tech start-ups: Exploring the role of founders' human capital and venture capital", Journal of Business Venturing, Vol. 25(6).

Cournède, B. and O. Denk (2015), "Finance and economic growth in OECD and G20 countries", OECD Economics Department Working Papers, No. 1223.

Cowling, M., P. Bates, N. Jagger, and G. Murray (2008), "Study of the impact of Enterprise Investment Scheme (EIS) and Venture Capital Trusts (VCT) on company performance", HM Revenue \& Customs Research Report 44.

Dahlquist, M. and G. Robertsson (2001), "Direct foreign ownership, institutional investors, and firm characteristics", Journal of Financial Economics, Vol. 59(3).

Dahlquist, M., L. Pinkowitz, R.M. Stulz, and R. Williamson (2003), "Corporate Governance and the Home Bias”, Journal of Financial and Quantitative Analysis, Vol. 38(1).

De Mooij, R.A. (2012), "Tax Biases to Debt Finance: Assessing the Problem, Finding Solutions", Fiscal Studies, Vol. 33(4).

De Mooij, R.A., and M.P. Devereux (2009), "Alternative Systems of Business Tax in Europe: An applied analysis of ACE and CBIT Reforms", Taxation Papers, Working Paper No.17.

Demmou, L., and I. Stefanescu (2018), "Labour Productivity Growth and Finance: The Role of Intangible Assets", OECD Economics Department Working Paper, forthcoming.

DeStefano, T., R. Kneller and J. Timmis (2019),"Cloud computing and firm growth", University of Nottingham research paper series, Research Paper 2019/09.

Devereux, M .P. and R. Griffith (1999), "The Taxation of Discrete Investment Choices", Institute for Fiscal Studies Working Paper Series, No. W98/16.

Devereux, M .P. and R. Griffith (2003), "Evaluating Tax Policy for Location Decisions", International Tax and Public Finance, Vol. 10.

Dirschmid, W., and W. Waschiczek (2005), "Institutional Determinants of Equity Financing in Austria", Financial Stability Report 9, Österreichische Nationalbank.

Djankov, S., La Porta, R., Lopez-de-Silanes, F. and A. Shleifer (2008), "The law and economics of selfdealing ", Journal of Financial Economics, Vol. 88.

Dlugosch, D. and S. Gul (2020), "The investment and leverage nexus: The case of Austria", OECD Economics Department Working Paper, forthcoming.

Doidge, C., G.A. Karolyi, and R.M. Stulz (2017), "The U.S. listing gap”, Journal of Financial Economics, Vol. $123(3)$.

Dornmayer, H., and B. Winkler (2018), "Skilled Labour Shortage in Austria", ibw research brief, Issue No. 101, September 2018.

ECB (2013), "Box 6 - Small and Medium-Sized Enterprises in the Euro Area: Economic Importance and Financing Conditions", European Central Bank Monthly Bulletin, July 2013.

ECB (2019), "Survey on the Access to Finance of Enterprises in the euro area - October 2018 to March 2019", May 2019.

EIB (2018), "EIB Investment Report 2018/2019: retooling Europe's economy".

European Commission (2013), "Evaluation of the Implementation of the 2006 Commission Communication on Business Transfers", Final report.

European Commission (2018), "Annual Report on European SMEs 2017/2018”, Final report.

European Commission (2017), "Effectiveness of tax incentives for venture capital and business angels to foster the investment of SMEs and start-ups", Final Report TAXUD/2015/DE/330. 
Fessler, P., and M. Schürz (2008), "Stock Holdings in Austria", Monetary Policy \& the Economy, Q2/08.

Fliess, B., and Busquets, C. (2006), "The Role of Trade Barriers in SME Internationalisation", OECD Trade Policy Working Paper, No. 45.

Frühwirth, M., and M. Kobialka (2011), "Do Equity Tax Shields Reduce Leverage? The Austrian Case", Available at SSRN: https://ssrn.com/abstract $=1458245$.

Gal, P., Nicoletti, G., Renault, T., Sorbe, S., and C. Timiliotis (2018), "Digitalisation and productivity: In search of the holy grail - Firm-level empirical evidence from EU countries", OECD Economics Department Working Papers, No. 1533.

Genser, B. (2002), "Zur Reform der Unternehmensbesteuerung in Österreich", in Kompendium der österreichischen Finanzpolitik, ed. by E. Theurl, R. Sausgruber, and H. Winner, Springer-Verlag, Berlin.

Gassler, H., W. Pointner and D. Ritzberger-Grünwald (2018), "Funding growth and innovation in Austria - financing conditions for SMEs and start-ups", Financial Stability Report 36, Österreichische Nationalbank.

Giannetti, M., and Y. Koskinen (2010), "Investor Protection, Equity Returns and Financial Globalization", Journal of Financial and Quantitative Analysis, Vol. 45(1).

Gonzalez, M., A. Guzman, C. Pombo, and M.-A. Trujillo (2013), "Family firms and debt: Risk aversion versus risk of losing control", Journal of Business Research, Vol. 66(11).

Gordon, R.J. (2012), "Is U.S. Economic Growth Over? Faltering Innovation Confronts the Six Headwinds", NBER Working Paper No. 18315.

Hall, B.H. and J. Lerner (2010), "Chapter 14 - The Financing of R\&D and Innovation", in Handbook of the Economics of Innovation, Vol. 1.

Hanappi, T. (2018), “Corporate Effective Tax Rates”, OECD Taxation Working Papers, No. 38.

Heath, C. and A. Tversky (1991):"Preference and belief: Ambiguity and competence in choice under uncertainty", Journal of Risk and Uncertainty, Vol. 4(1).

Hebous, S. and M. Ruf (2017), "Evaluating the effects of ACE systems on multinational debt financing and investment", Journal of Public Economics, Vol. 156.Hellman, T., and S. Kavadia (2016), "Scaleup UK: Growing businesses, growing our economy", A report from the business school at the University of Cambridge and the University of Oxford, conveyed by Barclays, London.

Hölzl, W., Böheim , M., Friesenbichler, K.S., and T. Jud (2016), "KMU-Börsen in Europa“, Österreichisches Institut für Wirtschaftsforschung.

Hsu, P.-H. (2006), "Venture Capitalists and Cooperative Start-up Commercialization Strategy", Management Science, Vol. 52(2).

Hsu, P.-H., X. Tian, and Y. Xu (2014), "Financial development and innovation: Cross-Country evidence", Journal of Financial Economics, Vol. 112(1).

ibw (2018),“Skills and labour shortages in Austria”, Issue No. 101, September 2018.

IHS (2017), "Digitalisierung der Arbeit: Substituierbarkeit von Berufen im Zuge der Automatisierung durch Industrie 4.0", Studie im Auftrag des Sozialministeriums, Endbericht, Januar 2017.

Kerr, W.R., and R. Nanda (2015), "Financing Innovation", Annual Review of Financial Economics, Vol. 7.

KMU Forschung Austria (2014), "Unternehmensübergaben und -nachfolgen in Österreich - Status quo 2014: Aktuelle Situation und zukünftige Entwicklungen", Studie im Auftrag der Wirtschaftskammer Österreich - Gründerservice und des Bundesministeriums für Wissenschaft, Forschung und Wirtschaft.

LaPorta, R., F. Lopez-de-Silanes, A. Shleifer, and R.W. Vishny (1998), "Law and Finance", Journal of the Political Economy, Vol. 106(6). 
LaPorta, R., F. Lopez-de-Silanes, and A. Shleifer (2006), "What Works in Securities Laws", Journal of Finance, Vol. 61(1).

Lopez-Gonzalez, J. (2017), "Mapping the participation of ASEEAN small- and medium-sized enterprises in global value chains", OECD Trade Policy Papers No. 203, OECD Publishing Paris.

Lusardi, A. (2009), "Household Saving Behavior: The Role of Financial Literacy, Information, and Financial Education Programs" in C. Foote, L. Goette, and S. Meier (eds), "Policymaking Insights from Behavioral Economics", Federal Reserve Bank of Boston, 2009, pp. 109-149.

Mann, W. (2018), "Creditor rights and innovation: Evidence from patent collateral", Journal of Financial Economics, Vol. 130(1).

Mirrlees, J., A. Stuart, T. Besley, R. Blundell, S. Bond, S. Chote, M. Gammie, P. Johnson, G. Myles and J.M. Poterba (2011), "Tax by design: The Mirrlees Review", Oxford University Press.

Mullins, W., and A. Schoar (2016),"How do CEOs see their roles? Management philosophies and styles in family and non-family firms", Journal of Financial Economics, Vol. 199, p. 24-43.

Nassr, I.K. and G. Wehinger (2016), "Opportunities and limitations of public equity markets for SMEs", OECD Journal: Financial Market Trends, Vol. 2015/1.

Nickell, S. (1981), "Biases in Dynamic Models with Fixed Effects", Econometrica, Vol. 49(6).

EIB (2018), "EIB Group survey on investment and investment finance Country overview", European Investment Bank.

Eisele, A., and E. Nowak (2017): "The Real Effects of Improving Access to Capital Markets Financing: Evidence from European SMEs", CEPR Discussions Paper, No. DP12227.

OECD (2012), "Financing SMEs and Entrepreneurs 2012: An OECD Scoreboard", OECD Publishing, Paris.

OECD (2013), "OECD Skills Outlook 2013", OECD Publishing, Paris.

OECD (2016), "Megatrends affecting science, technology and innovation", in OECD Science, Technology and Innovation Outlook 2016, OECD Publishing, Paris.

OECD (2016b), "OECD/INFE International Survey of Adult Financial Literacy Competencies", OECD Publishing, Paris.

OECD (2017), "OECD Digital Economy Outlook 2017", OECD Publishing, Paris.

OECD (2017b), "Austria, Trade and Investment Statistical Note", OECD International Trade, foreign direct investment and global value chains.

OECD (2017c), "Going Digital: Making the Transformation Work for Growth and Well-Being", Meeting of the Council at Ministerial Level, 7-8 June 2017.

OECD (2017d), "The Missing Entrepreneurs 2017 - Policies for Inclusive Entrepreneurship", OECD Publishing, Paris.

OECD (2017e), "Entrepreneurship at a Glance 2017", OECD Publishing, Paris.

OECD (2017f), "Making Integration Work - Assessment and Recognition of Foreign Qualifications", OECD Publishing, Paris.

OECD (2018), "Supporting Investment in Knowledge Capital, Growth and Innovation", OECD Publishing.

OECD (2018b), "Financing SMEs and Entrepreneurs 2018", OECD Publishing, Paris.

OECD (2018c), "Science, Technology and Innovation Outlook 2018", OECD Publishing, Paris.

OECD (2018d), "OECD Reviews of Innovation Policy: Austria”, OECD Publishing, Paris.

OECD (2018e), "OECD Capital Market Review: Italy 2018 Mapping Report", OECD Publishing, Paris.

OECD (2018f), "Business transfers as an engine for SME growth", Policy Note SME Ministerial

Conference Mexico City. 
OECD (2018g), "The Role and Design of Net Wealth Taxes in the OECD", OECD Tax Policy Studies, No. 26.

OECD (2018h), "Settling In 2018: Indicators of Immigrant Integration", OECD Publishing, Paris.

OECD (2019a), "SME and Entrepreneurship Outlook", forthcoming.

OECD (2019b), "Adapting business framework conditions to deal with disruptive technologies", OECD Economics Department Working Paper, forthcoming.

OECD (2019c), "Supporting Entrepreneurship and Innovation in Higher Education in Austria", forthcoming.

OECD (2019d), "Economic Survey of Denmark", OECD Publishing.

OeNB(2019), "Financial Stability Report 27", June 2019.

Pahnke, A., and F. Welter (2018), "The German Mittelstand: antithesis to Silicon Valley entrepreneurship?”, Small Business Economics, Vol. 52(2).

Panier, F., Pérez-González, F., and P. Villanueva (2013), "Capital Structure and Tax: What Happens When You (Also) Subsidize Equity", mimeo.

Princen, S. (2012),"Taxes do affect corporate financing decisions: The case of Belgian ACE", CESifo working paper series, No. 3713.

Rajan, R.G. and L. Zingales (1998), "Financial Dependence and Growth”, American Economic Review, Vol. 88(3).

Raposo, I.G. and A. Lehmann (2019):"Equity finance and capital market integration in Europe", Bruegel Policy Contribution, Issue no. 3.

Requena-Silvente, F. (2005), "The Decision to Enter and Exit Foreign Markets: Evidence from U.K. SMEs", Small Business Economics, Vol. 25.

Rouzet, N. and J. Eberly (2018),"Intangibles, Investment, and Efficiency", American Economic Review Papers \& Proceedings, Vol. 108.

Robb, A.M., and D.T. Robinson (2014), "The Capital Structure Decisions of New Firms", The Review of Financial Studies, Vol. 27(1).

v. Rooij, M., A. Lusardi, and R. Alessie (2011), "Financial literacy and stock market participation", Journal of Financial Economics, Vol. 101(2).

Shleifer, A., S. Djankov, R. LaPorta, and F. Lopez-de-Silanes (2008), "The Law and Economics of SelfDealing", Journal of Financial Economics, Vol. 88(3).

Silgoner, M, B. Greimel-Fuhrmann, and R. Weber (2018), "Financial literacy gaps of the Austrian population", Monetary Policy \& the Economy, Q2/15.

Solnik, B., and L. Zuo (2012), "A Global Equilibrium Asset Pricing Model with Home Preference", Management Science, Vol. 58(2).

Sorbe, S., Gal, P., Nicoletti, G., and C. Timiliotis (2018), "Digital dividend: Policies to Harness the Productivity Potential of Digital Technologies", OECD Economic Policy Papers, No. 26.

Statistik Austria (2015), "Arbeitsmarktsituation von Migrantinnen und Migranten in Österreich", Bundesanstalt Statistik Österreich.

Ederer, S. (2018), "Austria's Economy Stays on the Growth Path. Economic Outlook for 2018 and 2019", WIFO Bulletin, WIFO, Vol. 23(4).

Wehinger, G. (2014),"SMEs and the credit crunch: Current financing difficulties, policy measures and a review of the literature", OECD Journal: Financial Market Trends, Vo. 2013/2.

WKO (2018), "Familienunternehmen in Österreich", wkoanalyse. 
ZEW (2016), "The Effects of Tax Reforms to Address the Debt-Equity Bias on the Cost of Capital and on Effective Tax Rates", Taxation Papers, No. 65, Centre for European Economic Research, European Commission.

Zangari, E. (2014), "Addressing the debt bias: A Comparison between the Belgian and the Italian ACE Systems", European Commission Taxation Papers, No. 44.

Zehrer, A. (2016), "Die Betriebsübergabe familiengeführter Unternehmen unter spezieller Berücksichtigung der Führungskompetenzen", in H. Siller \& A. Zehrer (eds.), Entrepreneurship \& Tourismus. Unternehmerisches Denken und Erfolgskonzepte aus der Praxis (pp. 99-108).

Zehrer, A. (2017), "Generationenwechsel in touristischen Familienunternehmen: Herausforderungen für die Destinationsentwicklung", in T. Bieger, P. Beritelli, Ch. Laesser (eds.), Markt- und Branchenentwicklungen im alpinen Tourismus. Schweizer Jahrbuch für Tourismus 2016/2017.

Zieniel, W., Gavac, K. Seidl, T., Bachinger, K., and P. Voithofer (2014), "Unternehmensübergaben und nachfolgen in Österreich", Studie im Auftrag der Wirtschaftskammer Österreich und des Bundesministeriums für Wissenschaft, Forschung und Wirtschaft 


\section{Annex 1.A. Is there a listing gap in Austria?}

\section{Introduction}

Stock markets in Austria are less well developed than in peer countries (Figure 2.15). In 2017, only 67 Austrian firms where listed on domestic stock markets compared to 137 in Denmark and 228 in Switzerland. ${ }^{1}$ This low level of development goes hand in hand with legal framework conditions that emphasize creditor rights over debtor rights and relatively low disclosure requirements, both which have been negatively associated with firms' equity ratios (LaPorta et al., 1998). This analysis examines whether, actual number of listings in Austria are in line with expected number of listings, taken salient features of the economy and the legal framework into account. Significant differences are informative for policymakers as they may point to structural obstacles not related to framework conditions, e.g. financial literacy and investor participation in stock markets. The analysis follows an established methodology from the literature on corporate governance, in particular the models of Doidge et al. (2017) and Djankov et al. (2008) are employed.

The empirical model provides a way to compare the actual number of listings on domestic stock markets with expected listings. The number of expected listings is modelled by taking key variables into account: the legal framework pertaining to the protection of minority shareholders against expropriation by corporate insiders and the level of development of the economy, as measured by GDP per capita ${ }^{2}$, following the seminal models of La Porta et al. (1997) and Djankov et al. (2008).

Protection of minority shareholders against expropriation from corporate insiders is measured using the anti-self-dealing index by Djankov et al. (2008). Examples of self-dealing include various forms of transfer pricing and corporate finance transactions like personal loans to insiders. Importantly, the index only captures corporate actions that respect laws regarding disclosure and approval and therefore refrains from any form of corporate crime. , i.e. the index asks the hypothetical question: "If a controlling shareholder wants to enrich himself while following the law, how difficult is it for minority shareholders to thwart such activity before it takes place and to recover damages if it does occur?" (Djankov et al., 2008). The index is based on answers to a hypothetical transaction between two companies and takes on values from 0 to 1 . Higher values indicate better protection of minority shareholders against expropriation from managers and/or controlling shareholders. The answers were provided by an international association of law firms for 72 countries based on legal rules in May 2003.

The regressions results depicted in Table A.1 are consistent with Austria having abnormally few listings. The model suggests that GDP per capita is a strongly associated with listings per capita. Further, a legal framework which provides better protection against expropriation from corporate insiders is significantly positively associated with a higher number of listings. Column 2 adds an indicator for countries other than Austria. If there is a systematic difference between listings per capita and the other covariates for nonAustrian countries and Austria, this indicator would be significantly different from zero. This dummy variable for countries other than Austria shows a positive sign, suggesting that - conditional on the model - listings per capita are on average lower than elsewhere. The analysis further uses panel regressions to construct the time-varying measure of the listing gap for Figure 2.18. 
Annex Table 1.A.1. Institutions, economic development, and listings per capita

\begin{tabular}{|c|c|c|c|c|c|}
\hline \multirow[t]{2}{*}{ Dependent variable: Log(Listings/Cap) } & \multicolumn{2}{|c|}{ Cross-Sectional regressions (2016) } & \multicolumn{3}{|c|}{$\begin{array}{c}\text { Panel regressions } \\
(2001-2016)\end{array}$} \\
\hline & (1) & $(2)$ & (3) & $(4)$ & $(5)$ \\
\hline \multirow[t]{2}{*}{ Log(GDP/Cap) } & $0.665^{* \star \star}$ & $0.677^{\star * *}$ & $0.653^{* * *}$ & $0.653^{* * *}$ & $0.661^{* * *}$ \\
\hline & $(0.101)$ & $(0.102)$ & $(0.085)$ & $(0.086)$ & $(0.088)$ \\
\hline \multirow[t]{2}{*}{ Anti Self-Dealing Index } & $1.239^{* \star}$ & $1.167^{*}$ & $1.400^{* *}$ & $1.400^{\star *}$ & $1.378^{* *}$ \\
\hline & $(0.597)$ & $(0.616)$ & $(0.536)$ & $(0.540)$ & $(0.551)$ \\
\hline \multirow[t]{2}{*}{ GDP Growth } & & & -0.008 & -0.008 & \\
\hline & & & $(0.022)$ & $(0.022)$ & \\
\hline \multirow[t]{2}{*}{ Non-AUT Dummy } & & $0.704^{* * *}$ & $0.419^{*}$ & $0.472^{* *}$ & $0.478^{* *}$ \\
\hline & & $(0.230)$ & $(0.215)$ & $(0.220)$ & $(0.222)$ \\
\hline \multirow[t]{2}{*}{ Constant } & $-4.685^{\star \star *}$ & $-5.479^{\star \star \star}$ & $-4.686^{\star \star *}$ & $-4.737^{\star \star *}$ & $-4.829^{\star \star *}$ \\
\hline & $(1.042)$ & $(1.112)$ & $(0.922)$ & $(0.924)$ & $(0.939)$ \\
\hline Year FE & & & $\mathrm{N}$ & $\mathrm{Y}$ & $\mathrm{Y}$ \\
\hline Year FE x non-AUT dummy & & & $\mathrm{N}$ & $\mathrm{N}$ & Y \\
\hline Observations & 54 & 54 & 958 & 958 & 958 \\
\hline R-squared & $44.78 \%$ & $45.27 \%$ & $45.26 \%$ & $45.27 \%$ & $45.27 \%$ \\
\hline
\end{tabular}

Note: Robust standard errors in parentheses. ${ }^{* * *} p<0.01,{ }^{* *} p<0.05,{ }^{*} p<0.10$

Source: OECD calculations.

The listing gap depends critically on the modelling of the number of expected listings. The analysis of Doidge et al. (2017) is extended to check whether the key finding, that Austria has abnormally few listings, is robust to changes in the model specification and variables employed, including using different indicators and additional control variables.

First, given that the anti-self-dealing index is based on data from 2003 (Djankov et al. 2008), the subsequent analysis will test the robustness of the main finding using a different, more timely, proxy for the legal framework related to stock markets to elicit whether Austria's listing gap is sensitive to this variable. Here, the analysis uses the 2014/2015 index of general protection of minority investors from the World Bank Doing Business Survey. This index encompasses regulations related to self-dealing but also other measures related to the protection of minority investors. Higher values indicate better protection of minority investors.

Second, three additional variables are introduced: domestic credit to private sector per cent of GDP, the depth of credit information index, and the rule of law index. The first indicator is regarded as a measure of a financial development in terms of size. The second indicator measures rules and practices affecting the coverage, scope and accessibility of credit information. Higher values indicate better credit information and tend to be associated with more developed credit markets and less well-developed equity markets. All indicators come from the World Bank's World Development Indicators or Doing Business Database.

The additional regressions show that the finding of abnormally few listings in Austria is robust to a different proxy for minority protection and other control variables. As expected, the index of minority protection is positively associated with listings. However, adding rule of law renders the coefficient estimate for GDP per capita and minority protection insignificant. Framework conditions related to the disclosure of credit information tend to be negatively associated with listings, although the level of domestic credit to the private sector appears to drive the number of listings. However, domestic credit is not significant any more once rule of law enters the specification, suggesting that it is not the level of domestic credit which matters but rather the overall level of development. 
Across all specifications, the estimated coefficient on the dummy for other countries than Austria remains strongly significant and positive, implying that Austria has abnormal few listings. This results holds even when the level of development of the economy, legal framework conditions pertaining to stock markets as identified in the previous literature (Djankov et al., 2008), overall institutional quality and other control variables are taken into account. In the cross-sectional regressions, the coefficient estimates range from around 0.7 to 1.5 , suggesting that if Austria were like the OECD average, it would have $72-250$ listings more.

Annex Table 1.A.2. Robustness: Cross-sectional regression model estimates

\begin{tabular}{|c|c|c|c|c|c|}
\hline & (1) & (2) & (3) & $(4)$ & $(5)$ \\
\hline \multirow[t]{2}{*}{ Log(GDP/Cap) } & $0.7126^{* * *}$ & $0.5522^{* * *}$ & 0.1879 & 0.1722 & 0.2387 \\
\hline & $(0.0857)$ & $(0.0921)$ & $(0.1445)$ & $(0.1433)$ & $(0.1441)$ \\
\hline \multirow[t]{2}{*}{ Index protection minority investors } & $0.0205^{* *}$ & $0.0185^{* *}$ & & & 0.0128 \\
\hline & $(0.0096)$ & $(0.0092)$ & & & $(0.0092)$ \\
\hline \multirow[t]{2}{*}{ Index depth credit info } & $-0.1792^{* * *}$ & $-0.1658^{* * *}$ & -0.0801 & $-0.0834^{*}$ & $-0.1212^{* *}$ \\
\hline & $(0.0583)$ & $(0.0538)$ & $(0.0512)$ & $(0.0493)$ & $(0.0542)$ \\
\hline \multirow[t]{2}{*}{ Domestic credit to private sector / GDP } & & $0.0063^{* *}$ & & $0.0053^{*}$ & 0.0039 \\
\hline & & $(0.0026)$ & & $(0.0032)$ & $(0.0030)$ \\
\hline \multirow[t]{2}{*}{ Rule of Law } & & & $0.8495^{\star \star *}$ & $0.6606^{* * *}$ & $0.5592^{* *}$ \\
\hline & & & $(0.2140)$ & $(0.2256)$ & $(0.2279)$ \\
\hline \multirow[t]{2}{*}{ Non-AUT dummy } & $1.0763^{\star * *}$ & $0.8162^{\star \star \star}$ & $1.5123^{\star * *}$ & $1.1820^{* * *}$ & $1.1569^{\star \star \star}$ \\
\hline & $(0.1748)$ & $(0.1863)$ & $(0.2293)$ & $(0.2618)$ & $(0.2520)$ \\
\hline \multirow[t]{2}{*}{ Constant } & $-5.7321^{* \star \star}$ & $-4.4853^{\star \star \star}$ & -0.9113 & -0.8170 & -1.8453 \\
\hline & (1.1551) & (1.1177) & $(1.2308)$ & $(1.2137)$ & (1.3946) \\
\hline Observations & 73 & 70 & 73 & 70 & 69 \\
\hline R-squared & $42.3 \%$ & $44.3 \%$ & $47.8 \%$ & $48.4 \%$ & $46.8 \%$ \\
\hline
\end{tabular}

Note: Robust standard errors in parentheses. ${ }^{\star * *} p<0.01,{ }^{* *} p<0.05,{ }^{*} p<0.10$

Source: OECD calculations.

\section{Notes}

1. Data source: World Bank Development Indicators. Data refers to end-of-year 2017.

2. GDP per capita based on purchasing power parity in constant 2011 USD. 